\title{
The popular model annelid Enchytraeus albidus is only one species in a complex of seashore white worms (Clitellata, Enchytraeidae)
}

\author{
Christer Erséus $^{1}$ (D) Mårten J. Klinth ${ }^{1} \cdot$ Emilia Rota $^{2} \cdot$ Pierre De Wit $^{3} \cdot$ Daniel R. Gustafsson ${ }^{4} \cdot$ Svante Martinsson $^{1}$
}

Received: 10 December 2018 / Accepted: 17 March 2019 /Published online: 11 April 2019

(C) The Author(s) 2019

\begin{abstract}
The white worm Enchytraeus albidus Henle, 1837 (Clitellata, Enchytraeidae) is easy to keep in laboratory cultures, and has therefore been employed as a model organism in basic and applied biological research. Its natural habitat includes terrestrial composts and wrack beds on seashores. However, the name E. albidus is currently used for a complex of morphologically similar and closely related species. We here revise the components of the E. albidus species complex based on a sample of 100 Enchytraeus specimens from 56 sites, most of which are across Europe. These samples were DNA-barcoded for the mitochondrial COI gene. A subset of them was sequenced for the nuclear ITS2 and H3 markers. Six species were delimited with strong support by the COI and ITS2 gene trees, as well as by a multi-locus species delimitation analysis. These species are identified morphologically and described as E. albidus s. str. (with designation of a neotype); Enchytraeus moebii (Michaelsen, 1885); Enchytraeus albellus Klinth, Erséus and Rota, sp. nov., E. cf. krumbachi (Čejka, 1913), E. sp. 1 (unnamed), and Enchytraeus polatdemiri Arslan and Timm, 2018. The last-mentioned species is a soda lake specialist, whereas E. albidus s. str. is both terrestrial and marine littoral; all other species occur only in seashores. The phylogeny of this group was estimated using the multi-species coalescent model. Monophyly of the E. albidus complex was recovered. Within this complex, three groups were recovered as monophyletic, but the relationship between them is unclear. One group comprises E. albidus s. str., E. albellus, and E. moebii; the second group E. cf. krumbachi and the unnamed E. sp. 1, and the third consists of only E. polatdemiri. This study serves as a framework for genetic identification of white worms used for experimental purposes.
\end{abstract}

Keywords White worms $\cdot$ Enchytraeus albidus $\cdot$ Species complex $\cdot$ Species delimitation $\cdot$ Molecular taxonomy $\cdot$ New species $\cdot$ Model organisms $\cdot$ Enchytraeus albellus sp. nov.

Electronic supplementary material The online version of this article (https://doi.org/10.1007/s13127-019-00402-6) contains supplementary material, which is available to authorized users.

Christer Erséus

christer.erseus@bioenv.gu.se

Mårten J. Klinth

marten.klinth@bioenv.gu.se

Emilia Rota

rota@unisi.it

Pierre De Wit

pierre.de_wit@marine.gu.se

Daniel R. Gustafsson

kotatsu@fripost.org

Svante Martinsson

svante.martinsson@bioenv.gu.se
1 Department of Biological and Environmental Sciences, University of Gothenburg, Box 463, SE-405 30 Göteborg, Sweden

2 Department of Physics, Earth and Environmental Sciences, University of Siena, Via P.A. Mattioli 4, IT-53100 Siena, Italy

3 Department of Marine Sciences, University of Gothenburg, Tjärnö, Hättebäcksvägen 7, SE-452 96 Strömstad, Sweden

4 Guangdong Key Laboratory of Animal Conservation and Resource Utilizations, Guangdong Public Laboratory of Wild Animal Conservation and Utilization, Guangdong Institute of Applied Biological Resources, 105 Xingang West Road, Haizhu District, Guangzhou 510260, China 


\section{Introduction}

Enchytraeus albidus Henle, 1837 is one of the first enchytraeids ever described and the type species of Enchytraeus Henle, 1837, which in turn is the type genus of the family Enchytraeidae Vejdovský, 1879. It is regarded as an opportunistic, littoral, or terrestrial annelid, typically found in decaying seaweed and algae on seashores, and in garden composts. Today, E. albidus, commercially known as the white worm, is an economically and scientifically important species, which is often mass cultivated, e.g., for fish food production. In addition, it is a popular model organism, used in biological research around the world, and there are hundreds of publications dealing with aspects of its ecology, life history, physiology, genetics, responses to toxic substances, etc. (e.g., Römbke 1989; Lock et al. 2000; Römbke and Moser 2002; Amorim et al. 2008, 2011; Gomes et al. 2013; de Boer et al. 2018).

E. albidus (with its currently accepted synonyms; Nielsen and Christensen 1959; Schmelz and Collado 2010; see also below) has been described morphologically in rather great detail by Henle (1837), Michaelsen (1886; as Enchytraeus moebii, a new combination for Archenchytraeus moebii Michaelsen, 1885), Čejka (1913; as Litorea krumbachi), Stirrup (1913; as Enchytraeus pellucidus), Backlund (1947; as Enchytraeus constrictus), Bell (1958), Nielsen and Christensen (1959), and Kasprzak (1986). Further suggested synonyms include Halodrilus littoralis Verrill, 1874, Enchytraeus sabulosus Southern, 1906, and Pachydrilus lacteus Claparède, 1861, although the latter was described from sexually immature specimens. Nielsen and Christensen (1959) diagnosed E. albidus as whitish to yellowish, 20-35 mm long, with 2-5 straight or slightly bent chaetae per bundle, clitellum covering XII-XIII, with peptonephridia, three pairs of dorsally merging pharyngeal glands, dorsal vessel from XIV-XVIII, "large seminal vesicle" often bulging forward to reach IX, sperm funnels 5-8 times longer than wide, vasa deferentia extending as far back as XXI and with "large penial bulbs." Morphological variation has been noted, e.g., in the shape of the spermathecal ampullae (Nielsen and Christensen 1959), and the thickness of the vasa deferentia (Lasserre and Erséus 1976). Yet, hitherto, the mainstream view has been to regard the many variants as conspecific.

At the time of his original work on E. albidus (1837), Dr. Jacob Henle was doing anatomical and physiological research at Johannes Müller's medical institute in Berlin, Germany (Robinson 1921). Henle did not mention the collecting site of his described material, but he stated that the species lives in moist soil and is "not seldom found" in flowerpots, and he created for it the new genus Enchytraeus, using the Gr. en = "in" and chytra= "pot." Thus, we may conclude that his E. albidus was obtained from terrestrial substrates in Germany, probably in or near Berlin, without a precise type locality. Moreover, no type material remains (Reynolds and Wetzel 2017).

In the subsequent literature, E. albidus (including its suggested junior synonyms) has been reported from many parts of the world, and the records are both from inland and marine littoral sites. Nielsen and Christensen (1959) summarized the distribution of E. albidus as follows: "Almost cosmopolitan, occurring in decaying seaweed, compost heaps, sewage beds, and effluents, etc." However, they also addressed the possibility that their definition of the species was too broad, a view also held by, e.g., Erséus and Gustafsson (2009), Schmelz and Collado (2010), and Arslan et al. (2018). Moreover, it can be noted that E. constrictus, E. moebii, E. sabulosus, H. littoralis, and L. krumbachi were all described from seashores.

Recently, a new species morphologically similar to E. albidus, Enchytraeus polatdemiri Arslan and Timm, 2018 (in Arslan et al. 2018), was described from Van Gölü, a soda lake in Eastern Turkey. It was genetically compared to E. albidus specimens from various sources, and the authors (Arslan et al.) concluded that an alleged E. albidus worm from Denmark, COI-sequenced by Christensen and Glenner (2010) for a phylogenic study of the family Enchytraeidae, represented another distinct species.

Over the years, we have assembled specimens of E. albidus s. lat. (a collective term for named or unnamed forms that at some point have been recognized under this taxon name) from a variety of habitats primarily in the Scandinavian Peninsula, but also Spain, Greece, Svalbard, and Greenland, and from a strain of cultures shared by laboratories in Germany and Portugal. The cytochrome $\mathrm{C}$ oxidase subunit 1 (COI) marker of ten specimens of this material was preliminary studied by Erséus and Gustafsson (2009), who found three distinct lineages (clades $\mathrm{A}-\mathrm{C}$ ) to be involved. In the present study, we analyze mitochondrial (COI) and nuclear loci (ITS2 and Histone 3), as well as morphological patterns in a large sample of the E. albidus complex (i.e., E. albidus and closely related lineages), with the aim to obtain the widest possible support for species delimitation. The definition of E. albidus Henle, 1837 s. str. is revised and anchored in the selection of a neotype among specimens in the German lab culture. We also present a taxonomical and morphological overview of the other taxa found in our assembled material. We show that there are morphological differences among the genetically supported species, and we provide evidence for the resurrection of at least one of the names earlier held in junior synonymy with E. albidus (e.g., by Christensen and Glenner 2010; see above): E. moebii (Michaelsen, 1885). Finally, using a smaller sample of specimens, we analyze the phylogeny of the E. albidus species complex, including also the Turkish freshwater taxon E. polatdemiri. 


\section{Material and methods}

\section{Specimens, and their preparation and morphological examination}

A total of 100 Enchytraeus specimens belonging to the E. albidus species complex from 56 different collecting localities were analyzed morphologically and genetically (as the ingroup) in this study (Fig. 1, Table 1). A majority of them conform to the traditional broad concept of E. albidus (see Nielsen and Christensen 1959), and were collected in seashores in Sweden, Norway (including Svalbard), and Greenland, by various collectors: from an indoor compost in Sweden (leg. Egil Boräng); an algal compost in Galicia, Spain (leg. Belén Reboreda Rivera); and lab cultures in Germany (leg. Jörg Römbke and Andreas Haller) and Portugal (leg. Mónica J. B. Amorim). We also included two white enchytraeids, likely to be part of the E. albidus complex, but both in early stage of sexual maturity, from the Greek island Skopelos in the Mediterranean Sea (leg. Christer Erséus), as well as specimens of $E$. polatdemiri from Lake Van, Turkey (leg. Naime Arslan), the latter species being suggested by Arslan et al. (2018) to be a close relative of E. albidus.

Five other species of Enchytraeus, belonging to the "buchholzi-group" (sensu Schmelz and Collado 2010), were selected as outgroups for the molecular analyses in this study.

For details about all specimens, their metadata and GenBank accession numbers for the sequences analyzed, see Table 1. Physical vouchers (with catalog numbers in Table 1), some of which serving as type material, are deposited in the

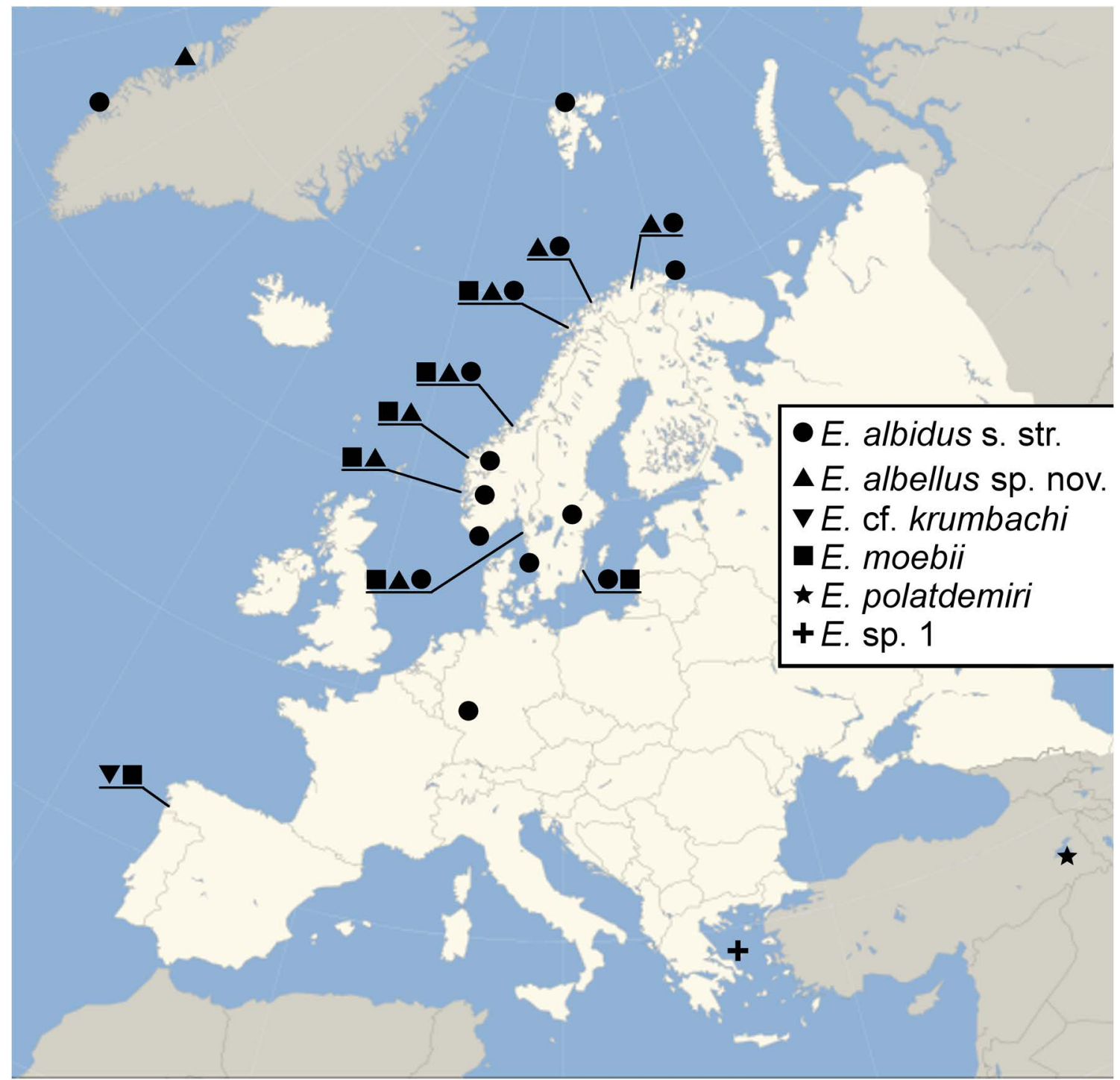

Fig. 1 Collecting localities and species found in each area. For the sake of clarity, several close localities along the Norwegian and Swedish coasts have been merged; see Table 1 for a detailed description on each locality 


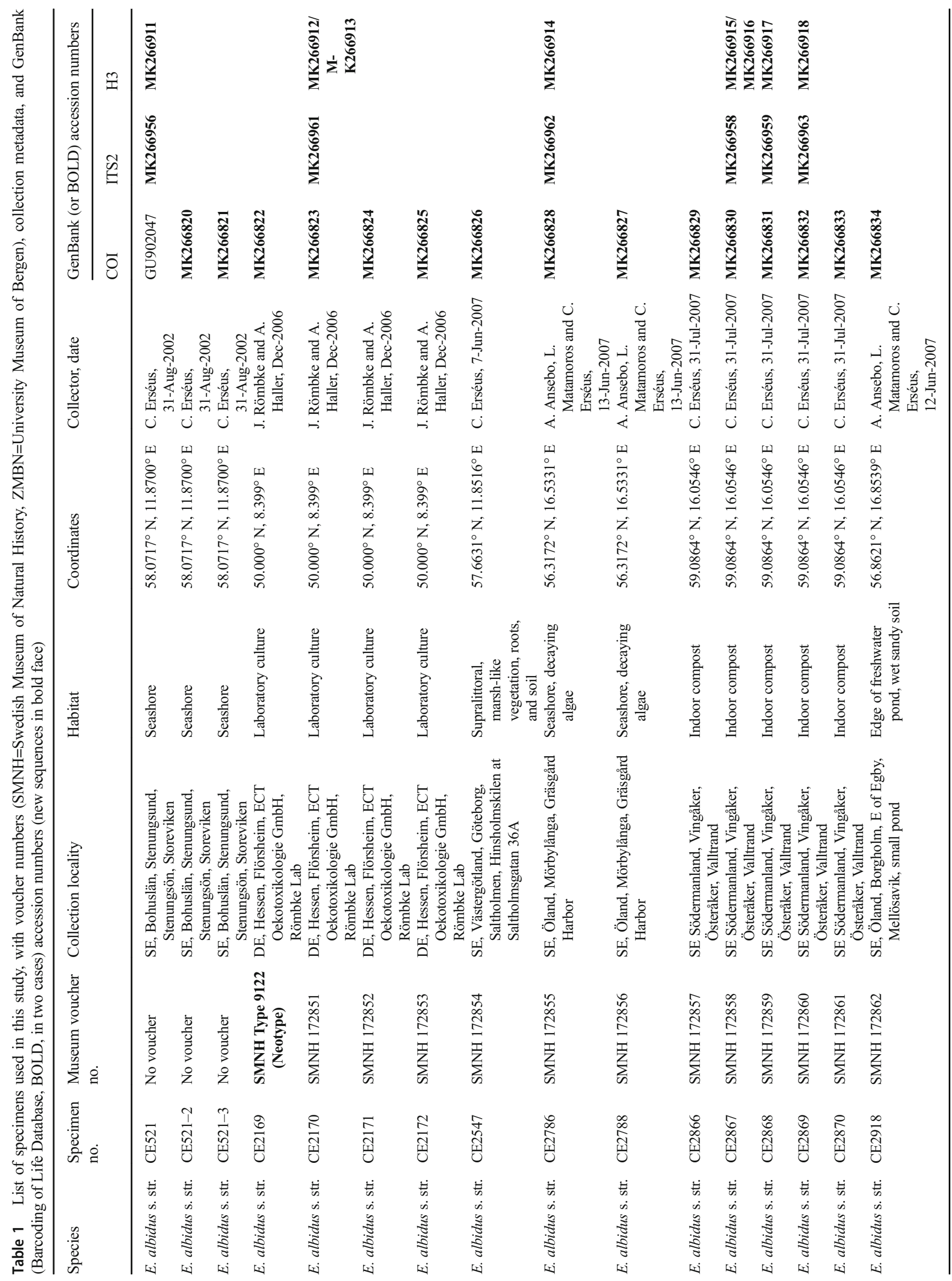




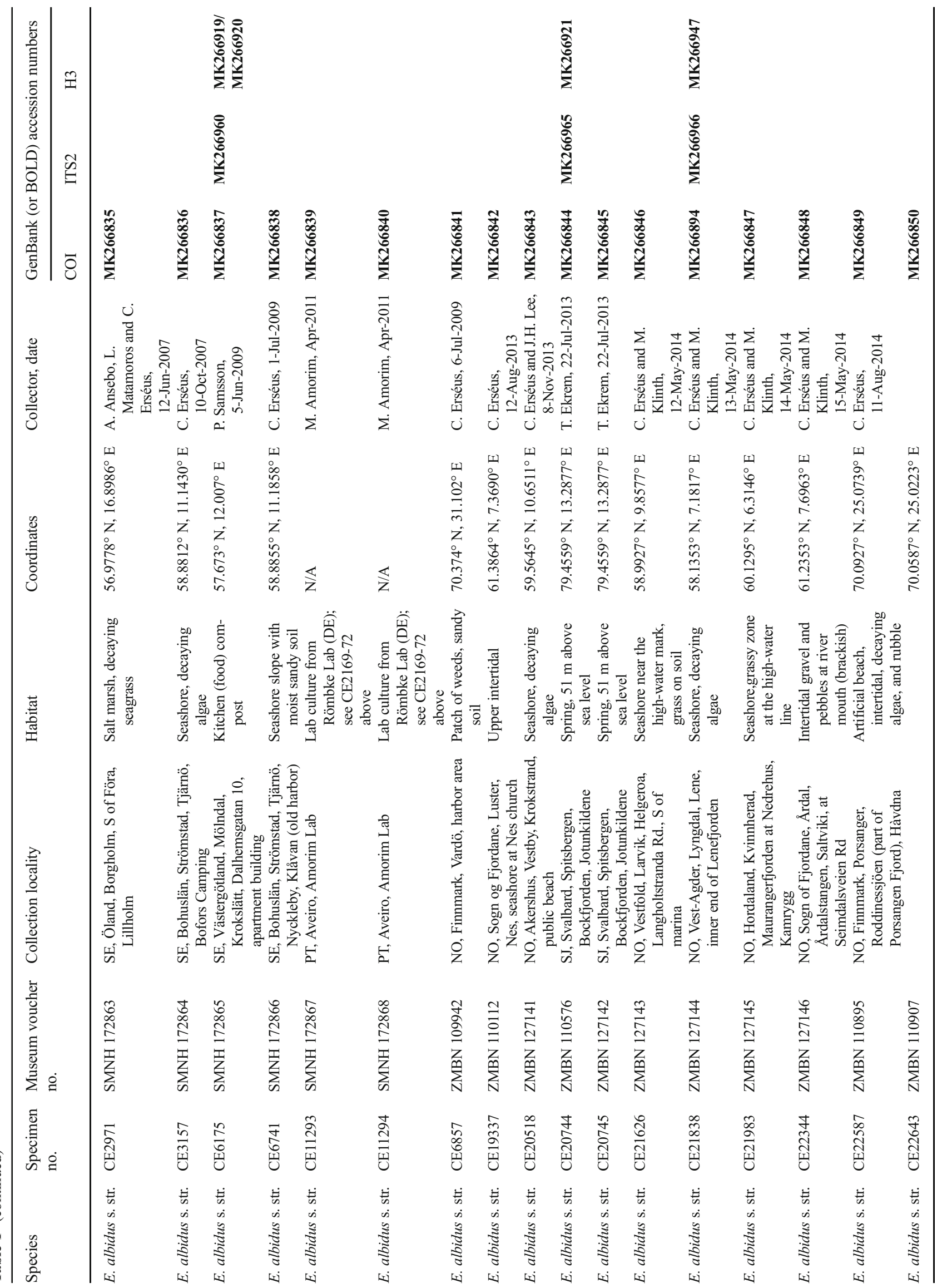




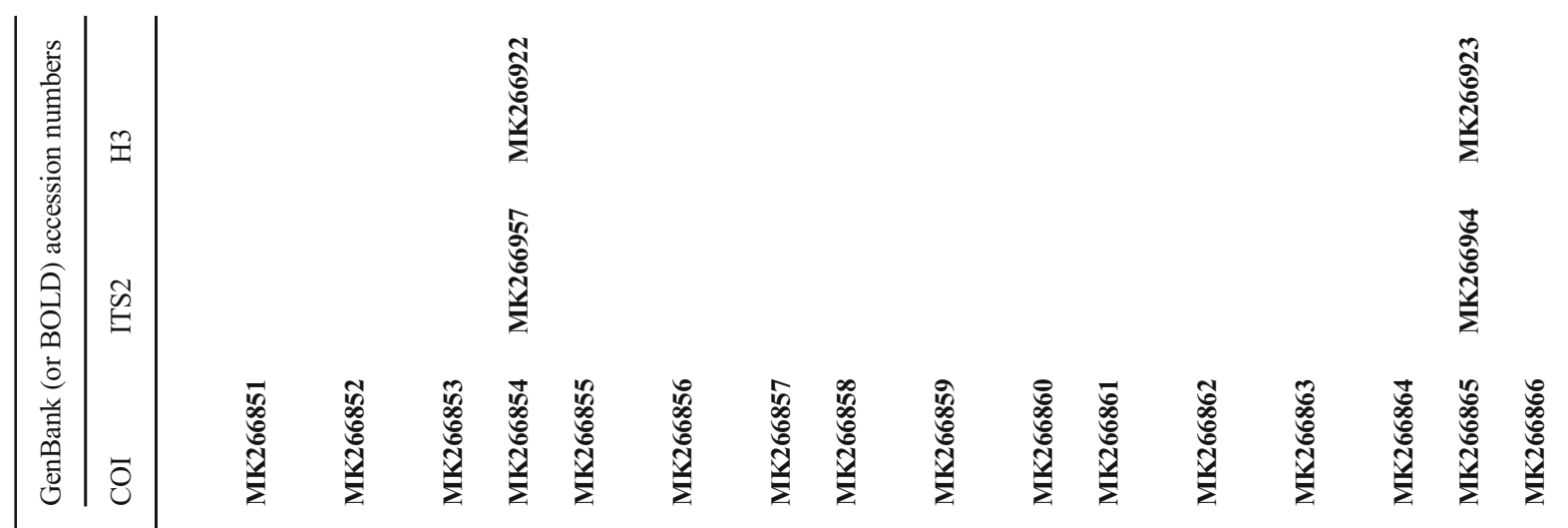

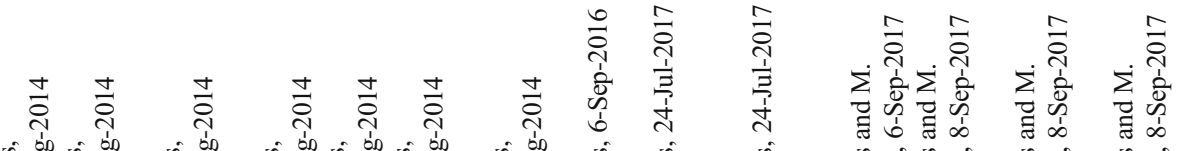

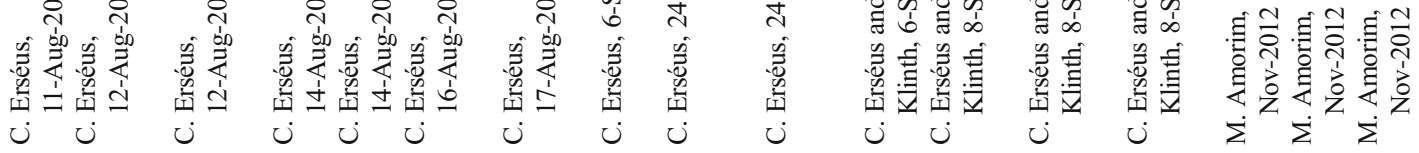

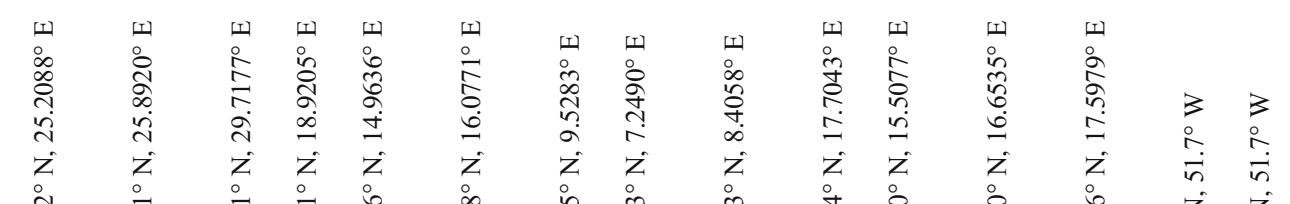

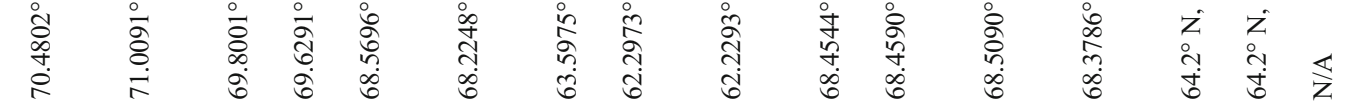

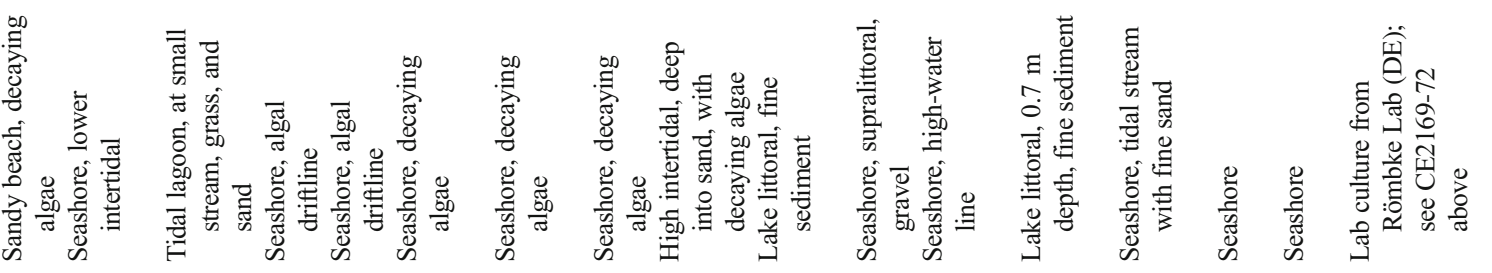

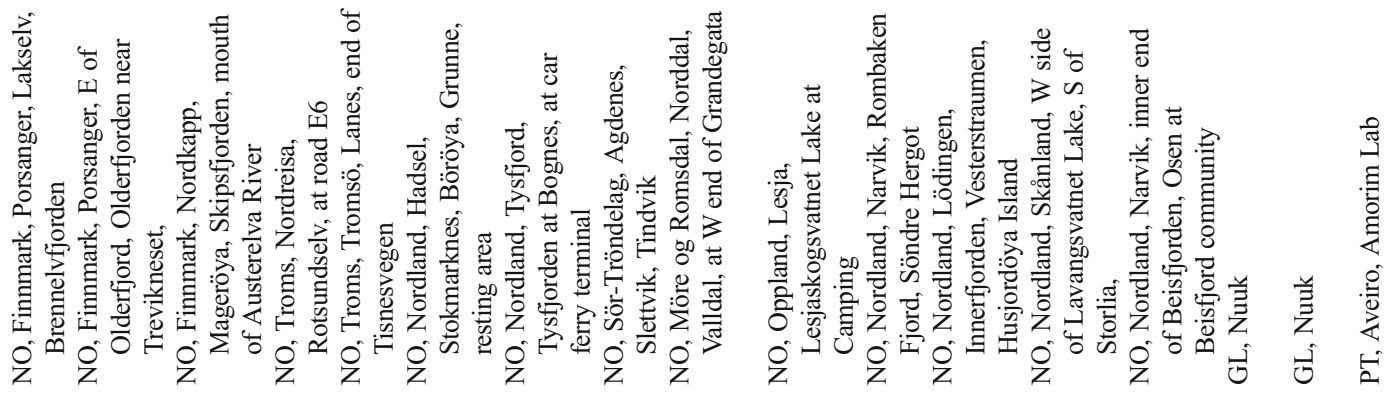

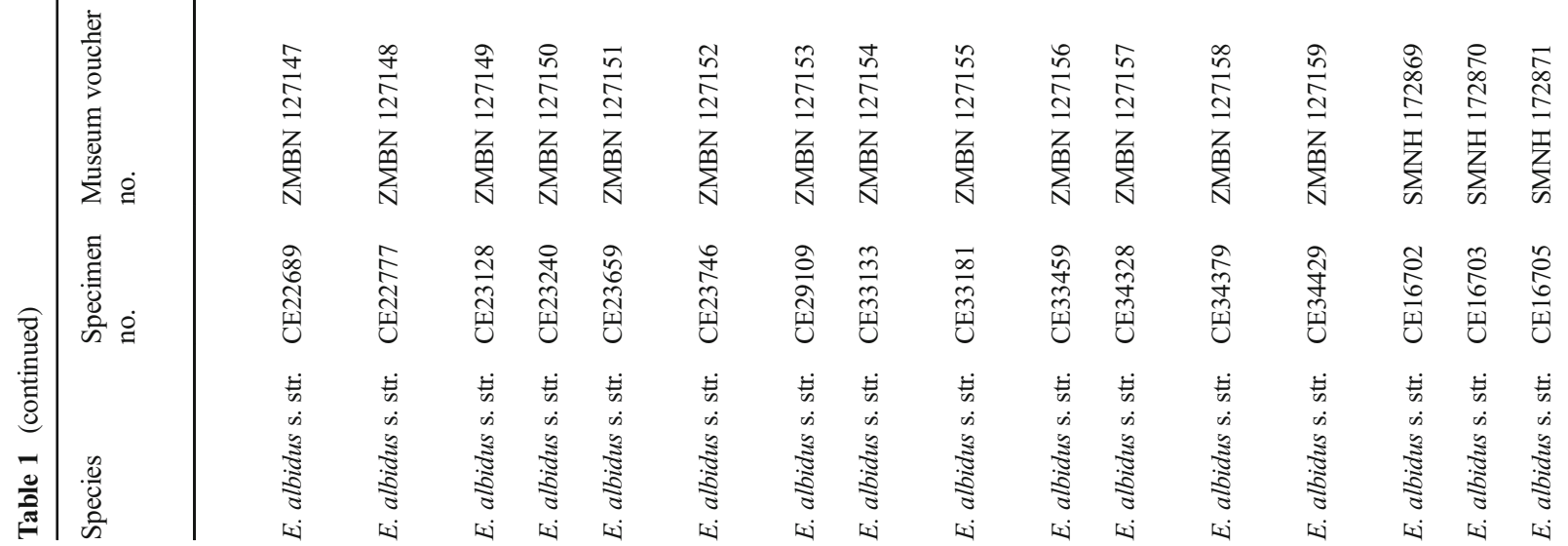




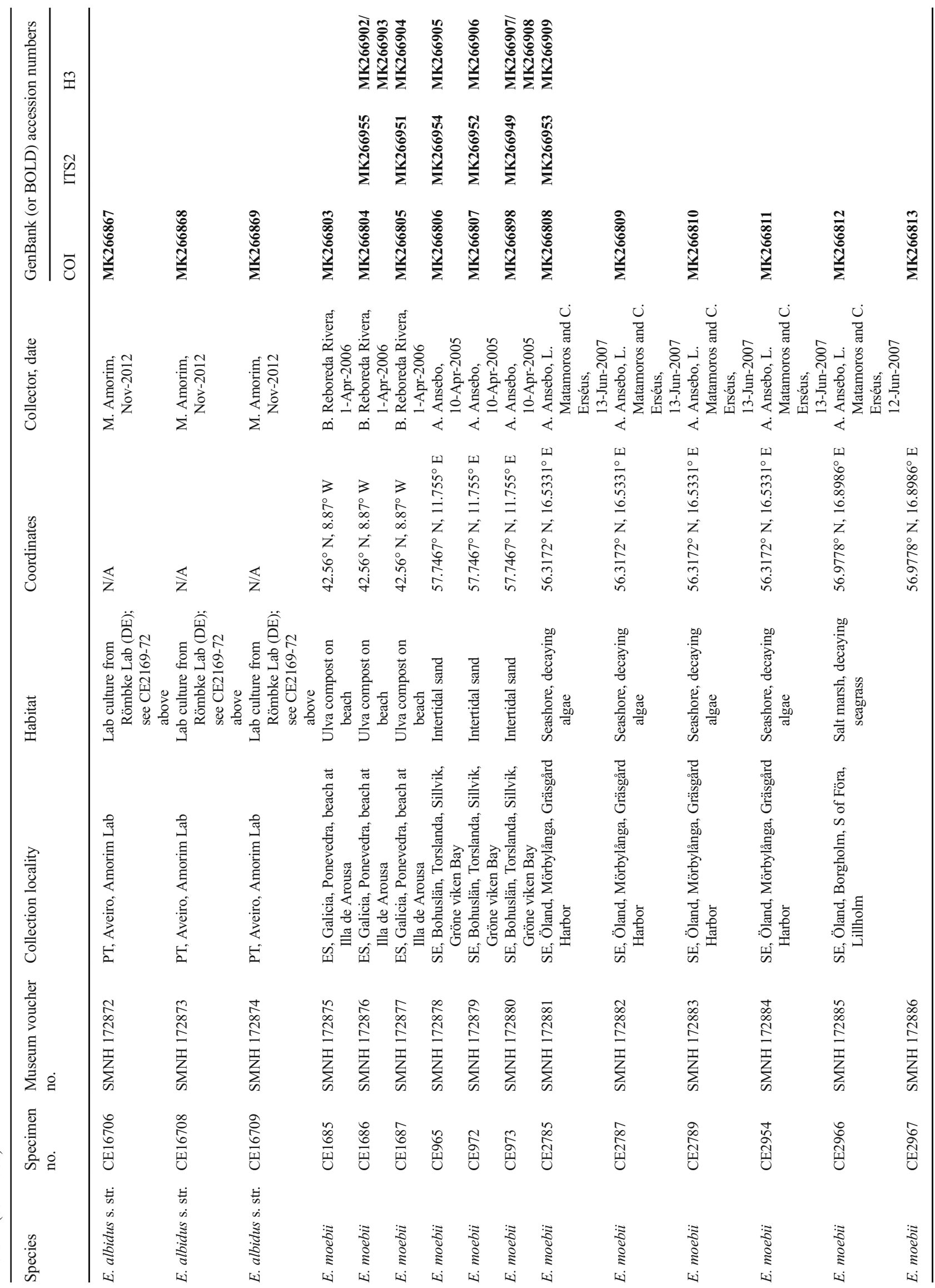




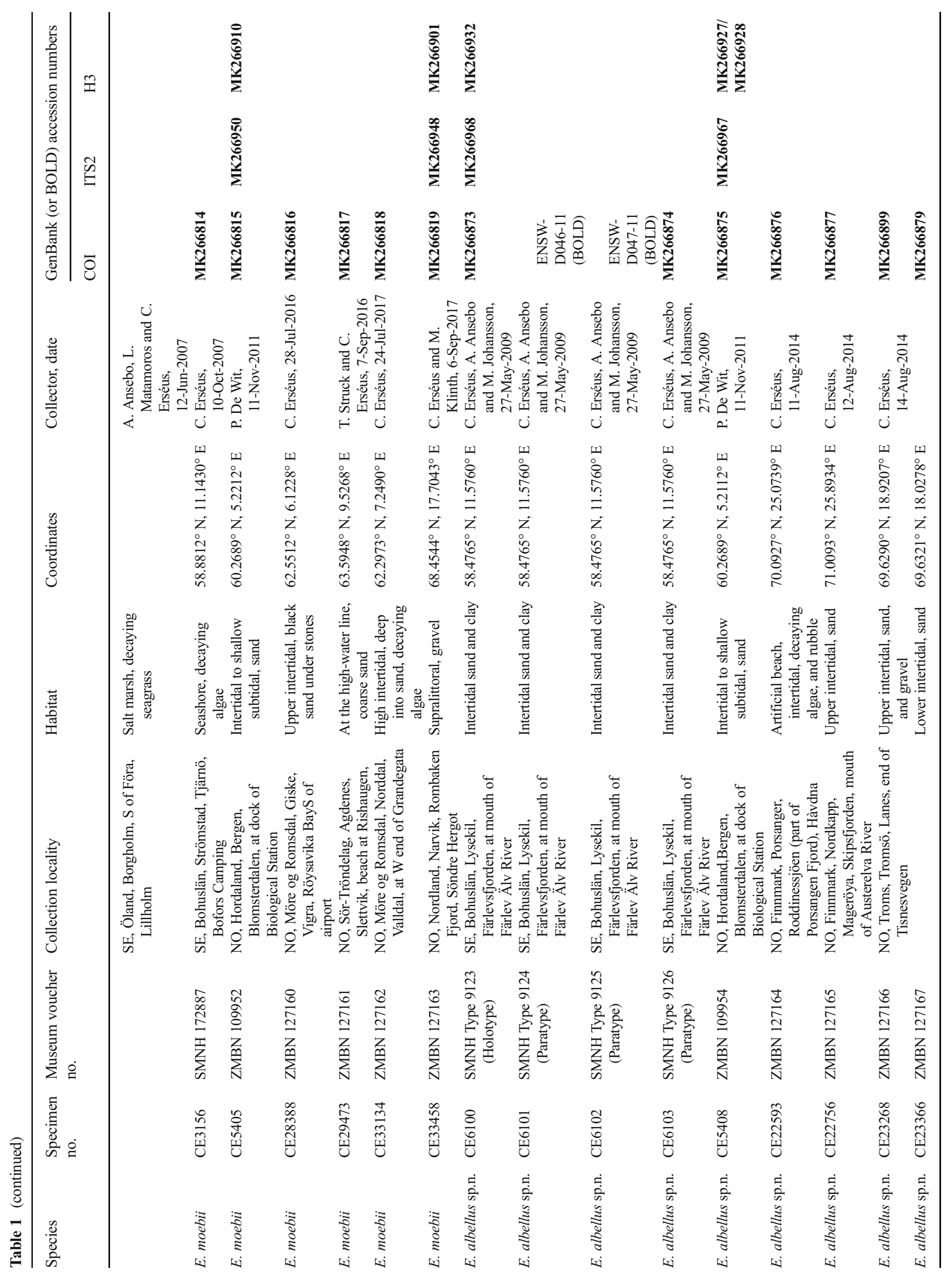




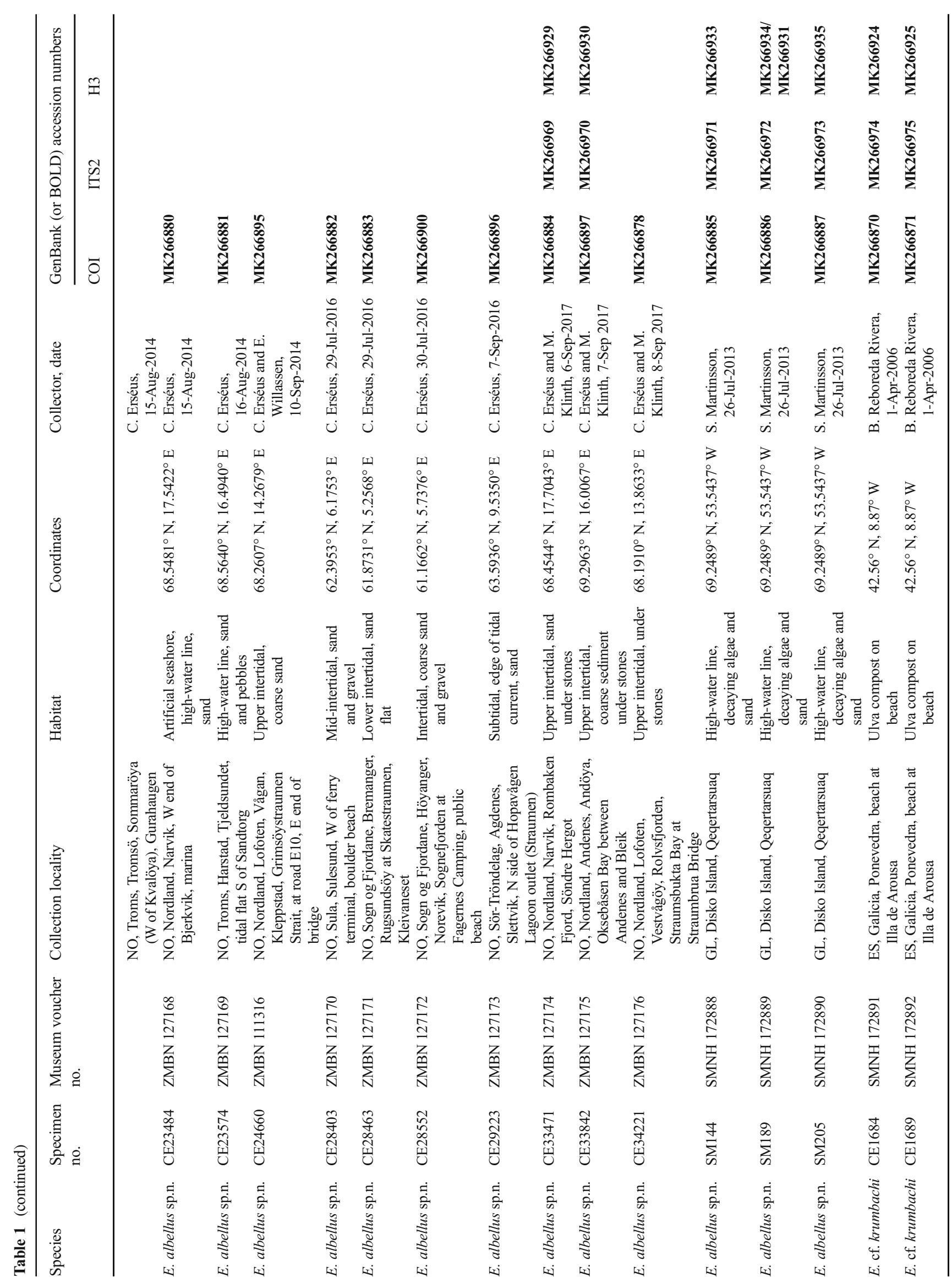




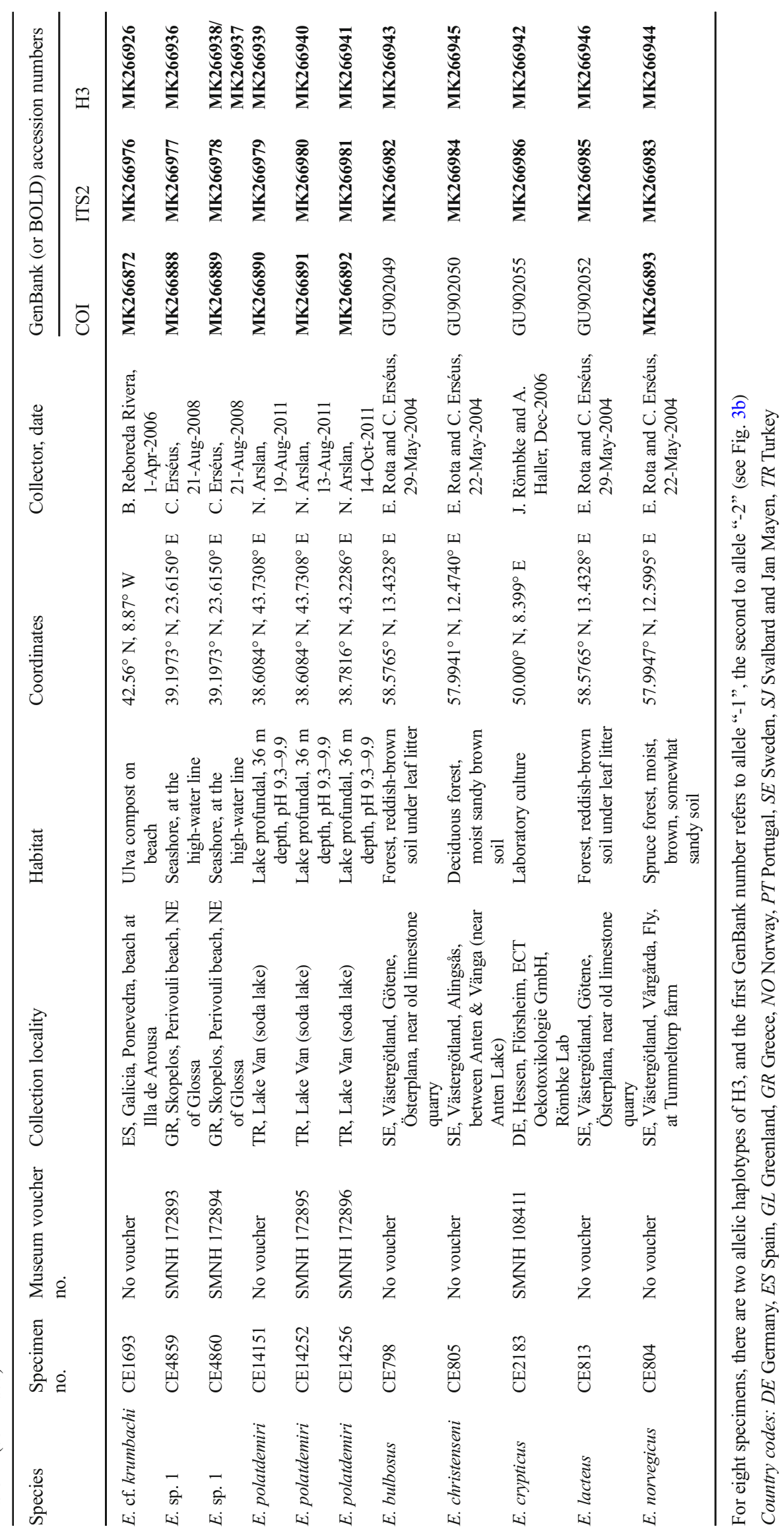


Swedish Museum of Natural History (SMNH), Stockholm, Sweden, or the University Museum of Bergen (ZMBN), Bergen, Norway.

The worms were fixed in $80-99 \%$ ethanol, each then divided into two parts. The larger (anterior) portion was preserved as a voucher for morphological observation, thus stained in alcoholic paracarmine, dehydrated in an ethanolxylene series, and finally compressed and mounted in Canada balsam under a coverslip on a microscope slide. The rear end of the specimen was used for DNA extraction. The mounted vouchers were examined under a compound microscope. Live examination of the sequenced worms was not undertaken, in order not to hamper the preparation of microscope slides of acceptable quality. The descriptions in the "Taxonomy" section below are based on a sample of the COI-barcoded specimens (see below). Due to the removal of the tail region for DNA extraction, none of the morphologically examined specimens is complete.

\section{Molecular work}

Procedures of DNA extractions, PCR, and sequencing have differed slightly between years but followed standard methods and recommended protocols. For both species delimitation and species phylogeny estimation, three genetic markers were included in the study: the mitochondrial cytochrome $\mathrm{C}$ oxidase subunit 1 (COI), and the nuclear histone $3(\mathrm{H} 3)$ and internal transcribed spacer 2 (ITS2). A few COI sequences are from previous studies (five were published by Erséus et al. 2010; a few others, not previously uploaded on GenBank, were preliminarily used by Erséus and Gustafsson 2009); all other data were newly generated (Table 1). The markers were amplified and sequenced using the PCR primers and programs listed in Table S1, and the resulting fragments were assembled using Geneious 8 (Biomatters Ltd., Auckland, New Zealand). COI sequencing was carried out for all the included specimens. Based on the COI data, we selected a representative subset of the worms to be sequenced for the other two markers. In the H3 dataset, a few specimens showed clear signs of heterozygosity, i.e., distinct double peaks at certain positions in the chromatograms. Therefore, we separated the H3 alleles using the PHASE algorithm (Stephens and Donnelly 2003, Stephens et al. 2001) as implemented in DNAsp v.5.10 (Librado and Rozas 2009); the phasing was run for 100 iterations after 100 initial burn-in iterations, with a thinning interval of 1 using default settings. For homozygous specimens, only one of the two identical alleles was kept.

To scan for additional records of the studied Enchytraeus species in the world, we compared our COI sequences with the global COI databases, GenBank, and BOLD (Barcoding of Life Database), using BOLD's Identification Engine at http://www.boldsystems.org/index.php/IDS_OpenIdEngine.

\section{Distance analysis and clustering of specimens}

COI, the recommended barcoding gene for the identification of animal species (Hebert et al. 2003), was used to divide the specimens into barcoding clusters (= putative species). Uncorrected genetic p-distances were calculated for the COI dataset (excluding outgroups) in MEGA 6 (Tamura et al. 2013). In total, six groups were found separated by barcoding gaps (where distances between the groups are clearly larger than the distances within the groups), and these groups were used as input species in the species delimitation analyses (see below).

\section{Multi-locus species delimitation}

Multi-locus species delimitation was performed using BPP v.3.3, for the two nuclear markers H3 and ITS2. As the COI dataset was used to divide the dataset into groups, and therefore matches the groups found by design, it was not included in the analyses. Joint Bayesian species delimitations and species tree estimations (Yang and Rannala 2010, 2014; Rannala and Yang 2013) were conducted; three analyses (A-C) with different population size (estimated by $\theta$ ) and divergence time $(\tau 0)$ priors were performed, using the same settings and priors as in Martinsson and Erséus (2018a) (A: $\theta$ 2, 400, 0 2, 200; B: $\theta 2,1000, \tau 02,200 ; C: \theta 2,2000, \tau 0 ~ 2,200)$; the analyses were run for 200,000 generations, discarding the first 4000 as burn-in. All analyses were performed three times to confirm consistency between runs. We considered species delimited with a PP (posterior probability) $>0.90$ in all analyses to be well supported. For clusters with a $\mathrm{PP}<0.90$, we accepted the best-supported more inclusive species.

\section{Phylogenetic estimations}

Both single gene trees and a species tree were estimated. The single gene trees were estimated using Bayesian Inference in MrBayes v.3.2.6 (Ronquist et al. 2012). The two protein coding genes $\mathrm{COI}$ and $\mathrm{H} 3$ were partitioned according to codon position; partitions were unlinked. Rate variation across sites was set to gamma distribution with a proportion of invariable sites; model jumping was implemented to integrate over substitution model space. The analyses ran for 10 million generations sampling every 10,000 generations, the first $25 \%$ were discarded as burn-in, and a majority-rule consensus tree was constructed.

The species tree was estimated using the multi-species coalescent (MSC) model as implemented through the *BEAST module in BEAST 1.8.2 (Drummond and Rambaut 2007; Drummond et al. 2012). A subset of 39 specimens that had all three markers sequenced (see the "Results" section) was included in the analysis. An XML input file was created in BEAUti 1.8.2 (Drummond et al. 2012). Substitution models were unlinked, for COI and ITS2 GTR $+\Gamma$ was used, for H3 TN93 $+\Gamma$ was used, and for all markers empirical base 
frequencies were used. Clock models were also unlinked across genes, with separate strict clocks, and clock rates estimated for each gene. The Yule process speciation prior and the piecewise linear with constant root population size prior were used, and the effective population size of the mitochondrial COI was set to half that of the nuclear markers by changing the ploidy level. The root height for the species tree was arbitrarily set to 1 using a strong normally distributed prior (mean 1, s.d. 0.01) for the tmrca (time to most recent common ancestor) for all taxa, combined with weak normally distributed priors for the clock rates (clock.rate) with mean 0.1 and s.d. 0.1 for all genes. For species population mean and mean growth rate priors, an exponential distribution with mean 1 was used. For all other priors, default settings were used. The analysis ran twice for 100 million generations, sampling every 10,000 generations. Tracer v1.6 was used to examine effective sample size (ESS) for parameters and determine burn-in, the runs were combined in LogCombiner 1.8 discarding the first $10 \%$ as burn-in, and trees were summarized using TreeAnnotator 1.8.2, using the maximum clade credibility tree. All trees were drawn in FigTree 1.4.2 (Rambaut 2014) and further edited in Adobe Illustrator.

Alignments and tree files were submitted to TreeBase (Submission: 23630) (http://www.treebase.org).

\section{Results}

All 105 specimens, 100 from the E. albidus species complex and five outgroups, were successfully sequenced for COI; of these, 39 specimens (including outgroups) were sequenced for both ITS 2 and $\mathrm{H} 3$. The COI alignment was 658 base pairs (bp) long, the ITS2 alignment was $478 \mathrm{bp}$ long, and the $\mathrm{H} 3$ alignment was 328 bp long, and after phasing included 46 sequences.
Table 2 Uncorrected pairwise genetic distance (p-dist. as \%) for COI for specimens of the Enchytraeus albidus species complex. Intraspecific distances are given as maximum p-dist, and interspecific as minimum $\mathrm{p}$ dist

\begin{tabular}{lrrrrrr}
\hline & 1 & 2 & 3 & 4 & 5 & 6 \\
\hline 1. E. albidus s. str. & 1.9 & & & & & \\
2. E. moebii & 9.3 & 2.7 & & & & \\
3. E. albellus & 10.4 & 11.0 & 3.0 & & & \\
4. E. cf. krumbachi & 13.9 & 15.0 & 14.8 & 2.9 & & \\
5. E. sp. 1 & 14.1 & 16.0 & 14.8 & 14.4 & 0.0 & \\
6. E. polatdemiri & 13.1 & 15.6 & 16.1 & 17.9 & 15.7 & 1.6 \\
\hline
\end{tabular}

\section{Distance analysis and clustering of specimens}

A global barcoding gap between 3.0 and $9.3 \%$ divided the specimens into six groups in the COI data set (Table 2). The maximum pairwise distances (p-dist) within the groups varied between $0.0 \%$ in E. sp. 1 and $3.0 \%$ in Enchytraeus albellus sp. nov. The minimal p-dist between the groups varied from $9.3 \%$ between E. albidus s. str. and E. moebii to $17.9 \%$ between E. cf. krumbachi and E. polatdemiri.

\section{Multi-locus species delimitation}

In all analyses, all groups, including the outgroups, were well supported as separate species, with a mean posterior probability (PP) of at least 0.99 . In general, the support was highest in analysis $\mathrm{C}$ and lowest in analysis $\mathrm{A}$. The mean support from each analysis is shown in the species tree (Fig. 2).
Fig. 2 Species tree for the E. albidus species complex (shaded), estimated using the multi-locus coalescent model. The number of included specimens for each species is given after the species name. Values above branches are posterior probability (PP) support values, values under terminal branches are mean PP from species delimitation analyses in BPP, written as: mean analysis $\mathrm{A} /$ mean analysis $\mathrm{B}$ / mean analysis $\mathrm{C}$. Scale measures the branch lengths in proportion to total tree length

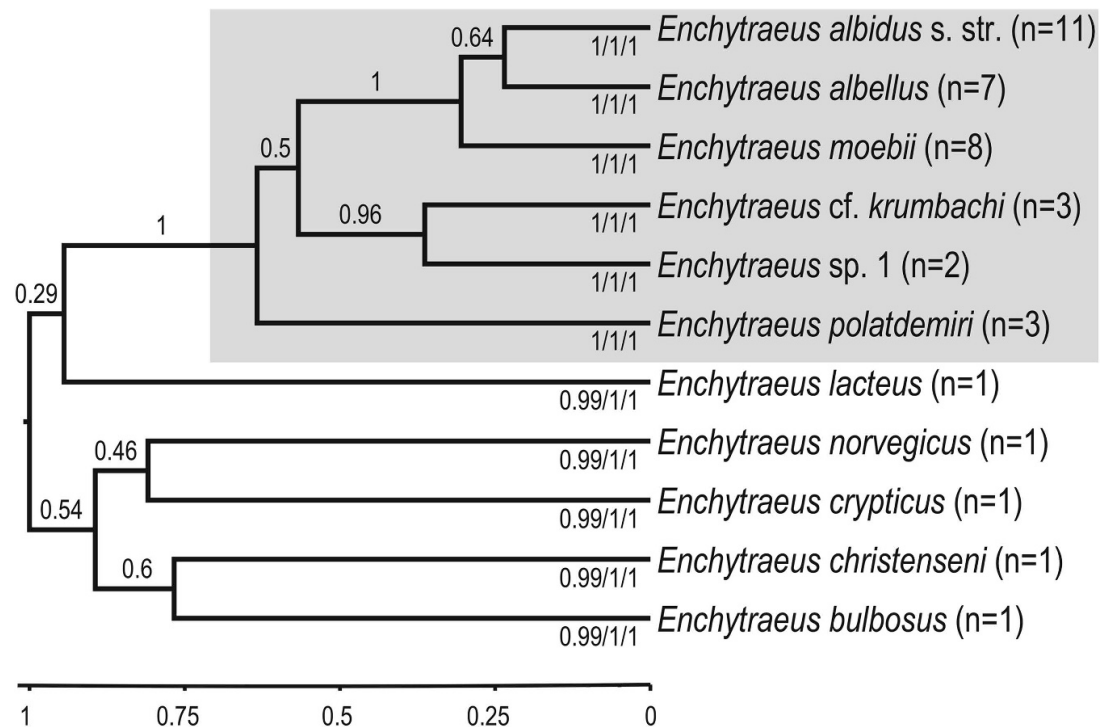




\section{Phylogenetic estimations}

In all three gene trees (Fig. 3a-c), the E. albidus species complex is recovered as monophyletic with high support. The COI (Fig. 3a) and ITS2 (Fig. 3c) gene trees are similar in topology, with E. polatdemiri recovered as sister to the remaining species of the complex. In both trees, E. albidus s. str., E. albellus, and E. moebii form a well-supported clade; in the ITS2 tree, E. albellus and E. albidus s. str. are sisters with good support, whereas in the COI tree, the relationships within this clade are unsupported (PP, 0.66). In the COI tree, E. cf. krumbachi and $E$. sp. 1 are sisters with maximum support, whereas in the ITS2 tree, E. cf. krumbachi is sister to the clade consisting of E. albidus s. str., E. albellus, and E. moebii with good support. The H3 tree (Fig. 3b) differs from the other two trees, but this seems to be due to the placement of the outgroups. If the outgroups are disregarded and the tree is instead rooted to E. polatdemiri, the $\mathrm{H} 3$ tree (Fig. S1) becomes similar to the COI and ITS2 trees. One clade comprises E. albidus s. str., E. albellus, and E. moebii; the sister of this clade is E. cf. krumbachi; Enchytraeus sp. 1 is then the sister to all these other species. Regardless of rooting, E. albellus is not recovered as monophyletic in the $\mathrm{H} 3$ trees.

In total, eight of the specimens studied show heterozygosity in $\mathrm{H} 3$, but the allelic variation is generally slight, and wherever this variation occurs, it is restricted to within the respective species groups recognized in Fig. 3b. Further, there are no differences in the amino acid sequence between the alleles. There is thus no evidence of gene duplication.

In the species tree (Fig. 2), the E. albidus complex is found monophyletic with maximum support. E. polatdemiri is the first branching species in this group, but the monophyly of the remaining species (the putative sister group of $E$. polatdemiri) is unsupported. The remaining species are found in two wellsupported clades, one consisting of E. albidus s. str., $E$. albellus, and E. moebii and the other consisting of $E$. cf. krumbachi and E. sp. 1.

\section{Taxonomy}

\section{Enchytraeus albidus species complex}

Diagnosis Large Enchytraeus worms, $>$ (7.5) $10 \mathrm{~mm}$; high segment number ( $>40)$; white to yellowish; ventral chaetae 3 or more in several bundles; esophageal appendages short, tube-like; vasa deferentia extending into segments posterior to clitellum (not always for E. polatdemiri); penial bulbs surrounded by several accessory glands. (E. polatdemiri is not further treated below.)
Enchytraeus albidus Henle, 1837 sensu stricto (Figs. 4-8)

E. albidus Henle, 1837: pp. 74-90, pl. VI, figs. 1-9; Bell 1958: pp. 2-11, figs. 1-10.

E. albidus partim; Nielsen and Christensen 1959: pp. 9192, figs. 95-100.

E. constrictus Backlund, 1947: pp. 8-13, figs. 4-6, pl. II, figs. $7-10$.

E. hortensis Goodrich, 1897: pp. 51-69, pl. V-VI, figs 115, 18-26, 28.

E. humicultor Vejdovský, 1879: p. 57, pl. V, figs. 1-11.

?E. pellucidus Friend, 1899: pp. 264-265.

E. pellucidus; Stirrup 1913: pp. 300-321, pl. XLVI, figs. 2, 4-5; pl. XLVII, figs. 10-13; pl. XLVIII, figs. 14-18; pl. XLIX, figs. 19-21.

?E. multiannulatus Altman, 1936: pp. 29-32, pl. XIII, figs. 108b, 109; pl. XIV, figs. 114, 117.

?E. multiannulatoides Altman, 1936: pp. 33-37, pl. XIII, figs. 105-108a.

Non E. sabulosus Southern, 1906: pp. 180-184, figs. 1-7 (strange spermathecae and chaetae; see "Remarks" below).

E. albidus "clade B"; Erséus and Gustafsson 2009.

E. albidus; Erséus et al. 2010.

Non E. albidus; Christensen and Glenner 2010: Table 1.

E. albidus "EA-SW, EA-I[1-2], EA-S[1-9]"; Arslan et al. 2018.

Non E. albidus "EA-DK"; Arslan et al. 2018.

Neotype SMNH Type Collection 9122 (CE2169), mature specimen, whole-mounted on a slide, from lab culture, ECT Oekotoxikologie GmbH, Flörsheim, Germany, Dec 2006, leg. J. Römbke and A. Haller. COI barcode: GenBank MK266822. Figures 5a-d, 6, and 7a are illustrations of this specimen.

Other material examined morphologically SMNH 172851 (CE2170), one specimen from the same lab culture as the neotype; SMNH 172854-172855 (CE2547 and CE2786), two specimens from Swedish seashores; and SMNH 172857-172861 (CE2866-2870), five specimens from a composting toilet in Sweden. All specimens sexually mature and COI barcoded. For more details, including GenBank accession numbers for genetic data, see Table 1.

Diagnosis Several chaetal bundles with more than three chaetae; sperm funnels 5-7 times longer than wide; vasa deferentia with uniform cell wall thickness; penial bulbs same size or larger than accessory glands; spermathecae sometimes with one or more diverticula.

External characters Color white (Fig. 4). Length of first 16-40 segments $>$ 4-12 mm (fixed, amputated specimens); first 12 


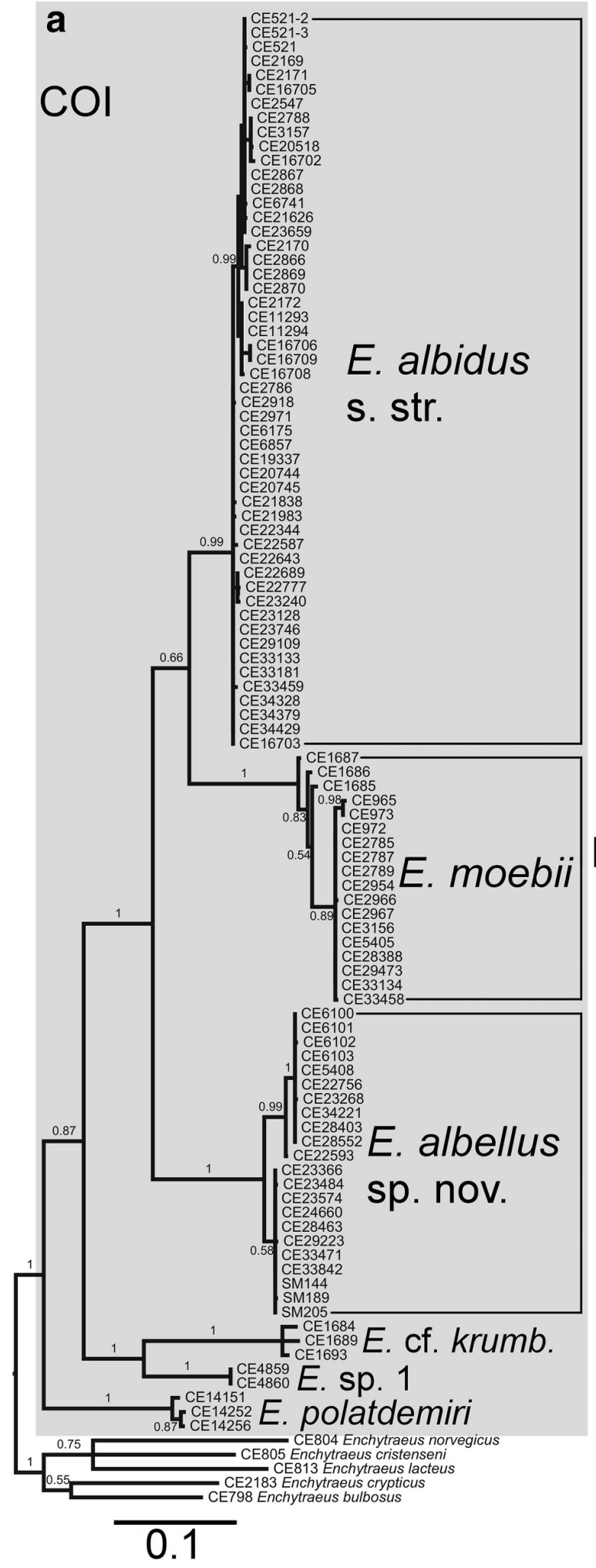

Fig. 3 Gene trees for the Enchytraeus albidus species complex (shaded), estimated by using Bayesian Inference. a COI. b H3 (specimens marked with "-1" or "-2" after the species name are heterozygous and the

segments (anterior end to clitellum) 2.6-3.3 mm long; width at clitellum $0.57-1.08 \mathrm{~mm}$. Chaetae straight or slightly curved
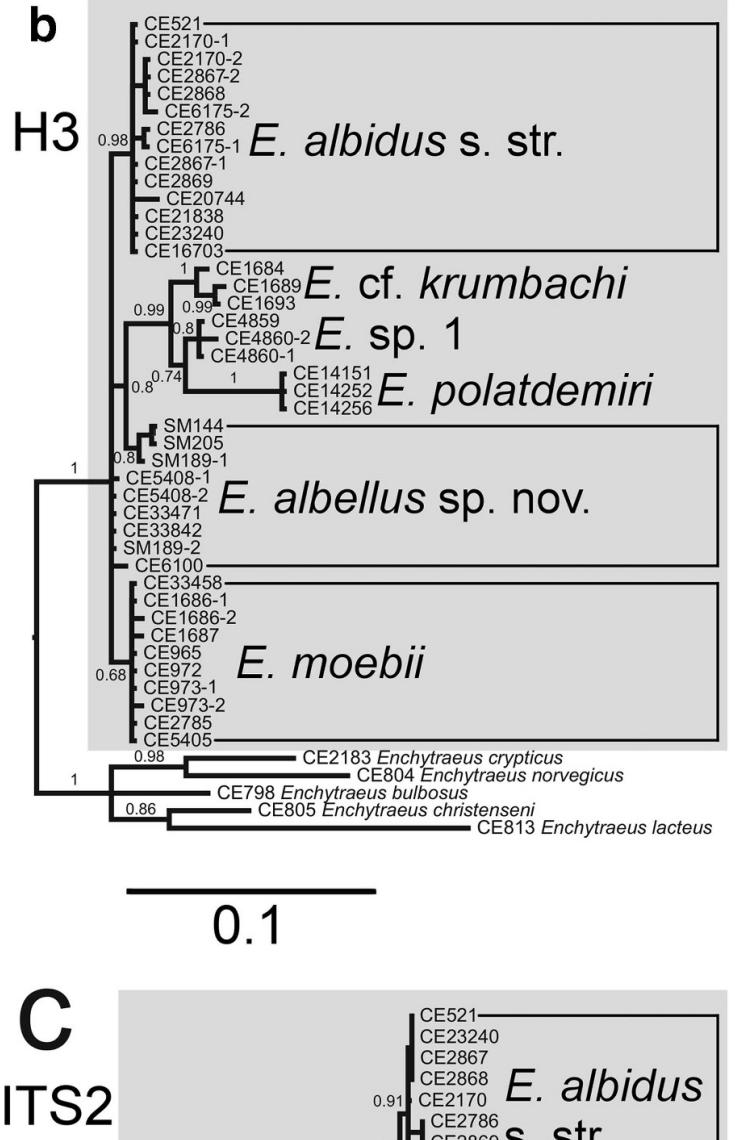

E. albidus
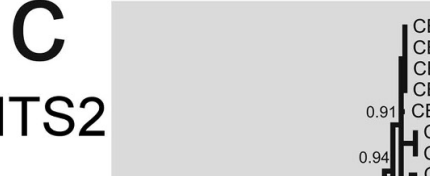

CE523240

CE2867

$H_{\mathrm{C} E 2869}^{\mathrm{CE} 2786} \mathrm{~S}$. Str.

CE2869 4 CE20744

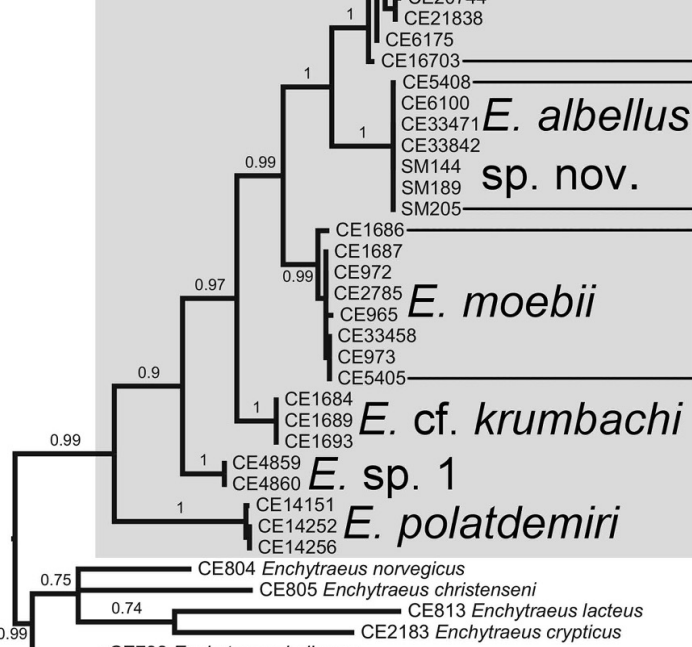

CE2183 Enchytraeus crypticus

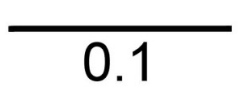

numbers indicate different alleles from the same specimen). c ITS2. In the trees, posterior probability support values are given at the branches; scale bars indicate expected number of substitutions per site

(Fig. 5c). Lateral bundles with 3-4(5) chaetae anterior to clitellum, 2-3 in XII, (2)3 chaetae in postclitellar segments. 
Ventral bundles with 3-5 chaetae anterior to clitellum, missing in XII, 2-4 chaetae in postclitellar segments. Chaetae longest in preclitellar ventral and lateral bundles (VIII-XI) measuring 80-130 $\mu \mathrm{m}$ long, about 5-8 $\mu \mathrm{m}$ wide. Clitellum extending over XII-1/2XIII (Fig. 5a). Head pore between prostomium and peristomium. Epidermis with transverse rows of gland cells. In some specimens, a deep transversal groove indenting the lateroventral body wall between segments IV and V; this is evidently the feature described by Backlund (1947: fig. 4).

Internal characters Coelomocytes numerous, 10-20 $\mu \mathrm{m}$ long, round, oval or spindle-shaped, granulated, and with distinct nucleus. Paired pharyngeal glands in IV, V, and VI. First pair of glands small, third pair usually largest (Fig. 5a); second and third pairs converging dorsally, dorsal junction in first pair not always evident. Esophageal appendages (peptonephridia) extending from dorsal wall of esophagus in III. Dorsal vessel originating in XIII-XVII, usually XIV or XV. Nephridia in 6/7-9/10 and from $13 / 14$ to $16 / 17$ at least, $110-175 \mu \mathrm{m}$ long, anteseptale consisting of funnel only, postseptale elongate ovoid, with posteroventral efferent duct (Fig. 5d). Brain longer than wide, posterior margin straight or slightly indented (Fig. 5b).

Male genitalia paired. Testes in XI, each surrounded by irregularly lobed mass representing different stages of spermatogenesis enclosed by peritoneal sac; testis sacs bulging forwards into X, sometimes into IX or even VIII (Fig. 5a). Sperm funnels in XI, 505-1085 $\mu \mathrm{m}$ long, 105-190 (240) $\mu \mathrm{m}$ wide at the widest point, making them about 5-7 times longer than wide, funnels tapering towards vasa deferentia. Vasa irregularly coiled in XII-XVIII or even XX, about $30-45 \mu \mathrm{m}$ wide with 5-10 $\mu \mathrm{m}$ thick wall along ental and ectal portions, gradually widening towards mid portion, which makes up most of vas' length and is about 35-55 $\mu \mathrm{m}$ wide with 10-15 $\mu \mathrm{m}$ thick wall. Vasa ciliated, without conspicuous musculature. Vasa seemingly not penetrating penial bulbs. Ventral surface of XII with invaginations creating two recesses with overhanging lips; male pores immediately beneath these lips (Fig. 6). Penial bulbs compact, round, 60$95 \mu \mathrm{m}$ in diameter, sheathed with muscles and surrounded by numerous accessory glands that are smaller or about same size as bulbs (Figs. 6a-b). Ovaries in XII. About three to eight mature eggs present at a time.

Spermathecae in V, with ectal pores at lateral lines. Ectal duct of spermatheca abruptly widening into sac-like ampulla (Fig. 7a-d) laterally connected to esophagus; ampulla often bearing one or more sac-like diverticula. Sperm filling lumen of ampulla and diverticula, heads of spermatozoa embedded in walls of diverticula, forming aggregates. Spermathecae $175-370 \mu \mathrm{m}$ long, $75-215 \mu \mathrm{m}$ wide at widest part of ampulla. Ectal duct surrounded by gland cells forming compact mass 75-155 $\mu \mathrm{m}$ in diameter at its widest part; in some (possibly all; see "Remarks") specimens, short, inner part of duct not covered by these cells. No obvious midventral subneural glands observed.

Specifics of neotype Length of first 16 segments (fixed) $>$ $4 \mathrm{~mm}$; first 12 segments $3 \mathrm{~mm}$ long; width at clitellum $0.72 \mathrm{~mm}$. Lateral bundles each with 3-4 chaetae anterior to clitellum, 3 chaetae in postclitellar segments. Ventral bundles each with 3-4 chaetae anterior to clitellum, 3 chaetae posteriorly. Chaetae up to $95 \mu \mathrm{m}$ long, about $5 \mu \mathrm{m}$ wide. Clitellum extending over XII-1/2XIII.

Coelomocytes numerous, $15 \mu \mathrm{m}$ long. Pharyngeal glands with ventral and dorsal lobes, first pair with smallest ventral lobes, third pair with largest. Dorsal lobes converging dorsally in at least first and third pairs. Dorsal blood vessel originating in XIII (or XV?). Nephridia in 6/7-9/10 and 13/14-15/16, about $155 \mu \mathrm{m}$ long.

Testes in XI, testis sacs extending forwards into IX. Sperm funnels $780 \mu \mathrm{m}$ long, $105 \mu \mathrm{m}$ wide at widest point, making them about 7 times longer than wide. Vasa irregularly coiled in XII-XIV, width from $30 \mu \mathrm{m}$ (with $7 \mu \mathrm{m}$ thick wall) in the proximity of penial bulbs to $35 \mu \mathrm{m}$ (with $10 \mu \mathrm{m}$ thick wall) in postclitellar loops. Penial bulbs compact, round, $70 \mu \mathrm{m}$ in diameter, surrounded by accessory glands of about the same size or smaller than penial bulbs. Ovaries in XII. One mature egg present.

Spermathecae in V, narrow ectal duct abruptly widening into sac-like ampulla (Fig. 7a). In one spermatheca, ampulla seemed divided into two sacs, one visibly connected to esophagus. Spermathecae $180 \mu \mathrm{m}$ long, $110 \mu \mathrm{m}$ wide at widest part of ampulla. Ectal gland $100 \mu \mathrm{m}$ in diameter at its widest part; innermost (short) part of duct clearly devoid of glands at least on one side (Fig. 7a). No obvious midventral subneural glands observed.

Remarks In the DNA-based phylogeny of Enchytraeidae proposed by Erséus et al. (2010), the specimen CE521_1 was included to represent $E$. albidus, which is fortunate, as we have now been able to confirm that it belongs to E. albidus s. str. However, in a coeval molecular assessment of the family, Christensen and Glenner (2010) used a specimen of E. albidus (from Northern Zealand, Denmark), which according to its COI sequence (GenBank \# GU453370) can now be identified as E. moebii (see below).

Our specimens (those studied morphologically) match the original description of E. albidus well in most characters, such as the number of chaetae, shape of nephridia and male genitalia, the latter with long sperm funnels. With regard to the coverage of glands along the spermathecal duct, we noted a short naked region near the base of the ampulla in some specimens (including the neotype), exactly as shown for various specimens depicted by Nielsen and Christensen (1959: figs. 95-97); however, we could not confirm this feature in all of our (fixed and whole-mounted) material. 


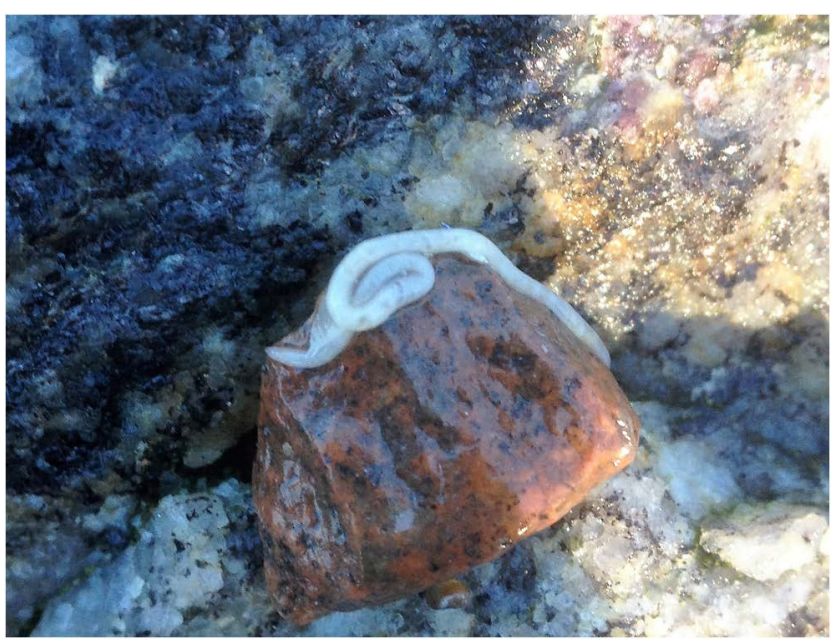

Fig. 4 Enchytraeus albidus s. str., live specimen, from the same locality as CE20518 (see Table 1). Photo: C. Erséus

E. albidus s. str. was originally described from potted soil (see the "Introduction" section). This is compatible with the habitat of our specimens, which were collected in terrestrial
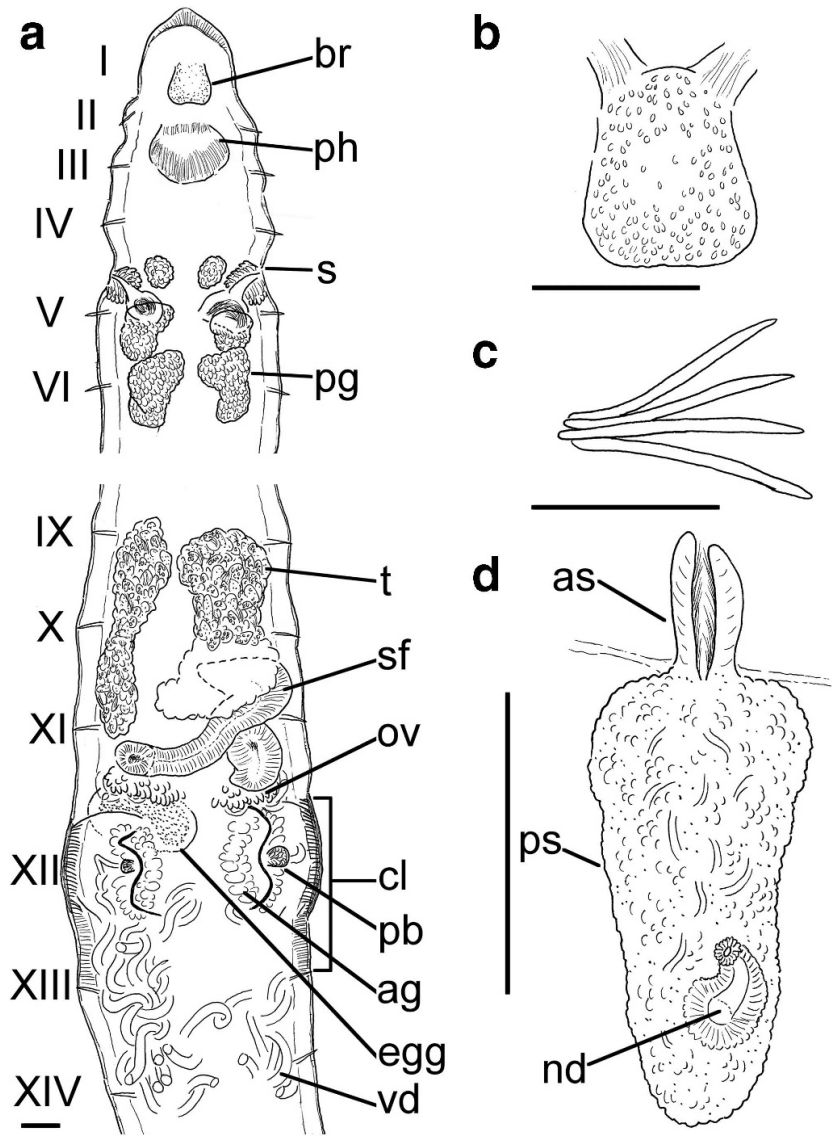

Fig. 5 Enchytraeus albidus s. str. a Internal morphology of segments IVI and IX-XIV viewed from dorsal side. b Brain. $\mathbf{c}$ Bundle of chaetae. $\mathbf{d}$ Nephridium. ag accessory glands, $a s$ anteseptale, $b r$ brain, $c l$ clitellum, $n d$ nephridial efferent duct, $o v$ ovary, $p b$ penial bulb, $p g$ pharyngeal glands (only ventral lobes illustrated), $p h$ pharyngeal pad, $p s$ postseptale, $s$ spermatheca, $s f$ sperm funnel, $t$ testis, $v d$ vas deferens. Scale bars $100 \mu \mathrm{m}$

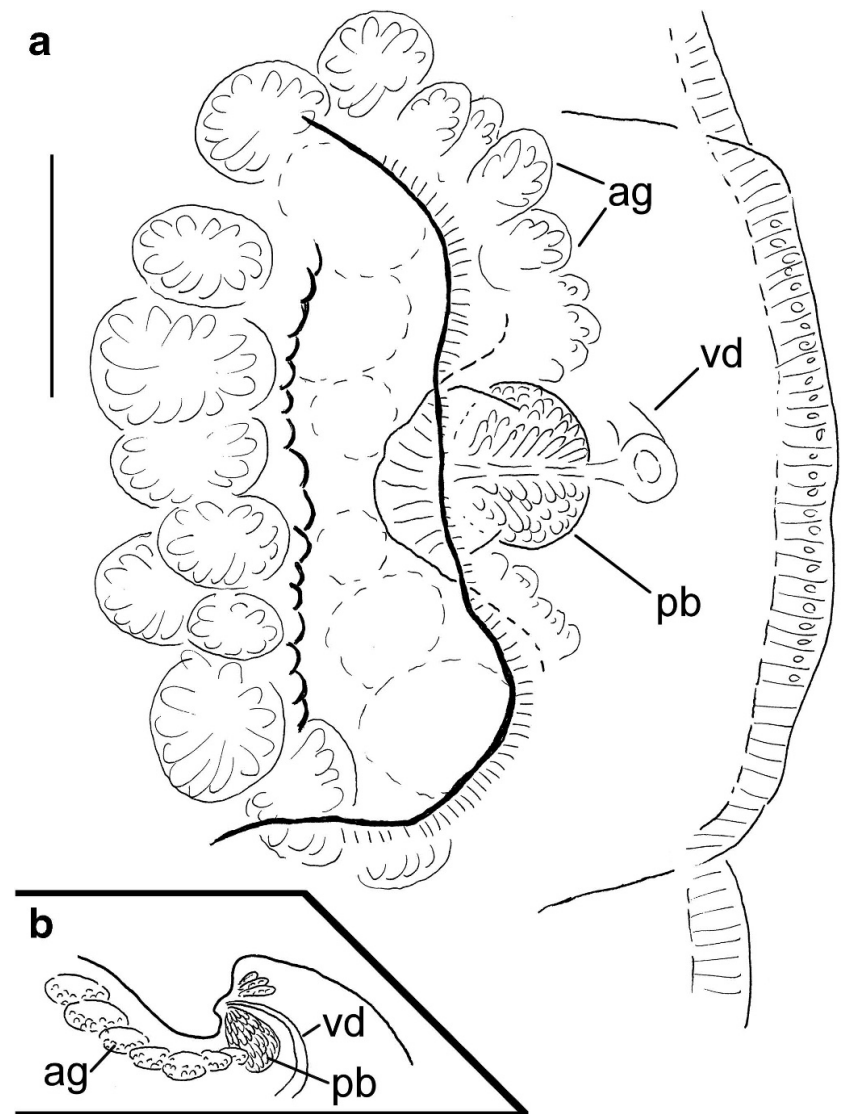

Fig. 6 Enchytraeus albidus s. str. a Male apparatus viewed dorsally. b Schematic illustration of the male apparatus in cross section. ag accessory glands, $p b$ penial bulb, $v d$ vas deferens. Scale bar $100 \mu \mathrm{m}$

habitats, including lab cultures, as well as in seashores. It should be noted that all the other species of the E. albidus complex (except $E$. polatdemiri) are exclusively known from sites near the sea.

To clarify the taxonomic status of $E$. albidus s. str., we have decided to designate a neotype of this species, under the qualifying conditions stated by the International Code of Zoological Nomenclature, Article 75.3. (http://www.iczn. org/code). The lack of old type material and the uncertainty of the original locality were mentioned in the "Introduction" section above, but from Henle's (1826) words, it appears that his material was from more than one German site, and more likely from a terrestrial habitat than the marine littoral. As we have access to sexually mature, DNA-barcoded specimens of E. albidus s. str. from a laboratory strain commonly used in Germany, we have assigned the name-bearing status to one of these specimens. This will stabilize the nomenclature of $E$. albidus, and permit the continued use of this name for the lineage most commonly used in applied studies (e.g., ecotoxicology). We present molecular evidence herein that the same strain as cultured for several years in Flörsheim (Germany) labs has also been used for scientific work in Aveiro (Portugal) and in other labs elsewhere in the world (J. Römbke, M. Amorim, pers. comm.). The cultures were part 


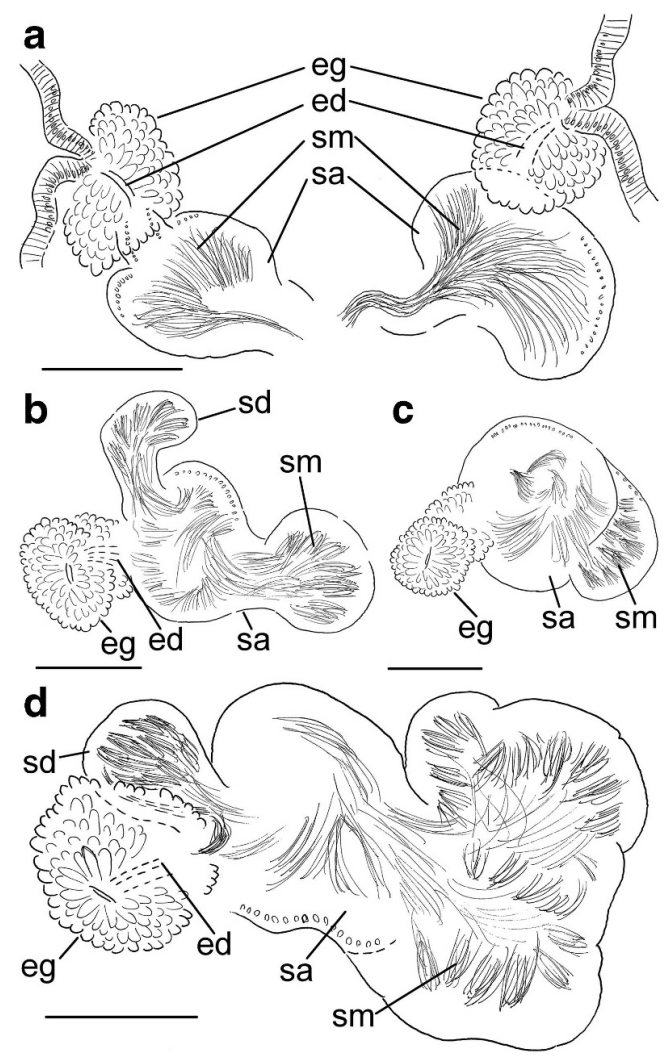

Fig. 7 Enchytraeus albidus s. str. a-d Spermathecae. ed ectal duct, eg ectal gland, $s a$ spermathecal ampulla, $s d$ spermathecal diverticulum, $s m$ sperm. Scale bars $100 \mu \mathrm{m}$

of an international ringtest during the development and validation of the Enchytraeid Reproduction Test (ERT; Römbke and Moser 2002). Unfortunately, it is not possible to trace the barcoded worms back to one specific geographic site or breeder.

E. albidus s. str. can be distinguished from the other species of the complex considered here by two main characters: the proportions of the sperm funnels and the morphology of the copulatory organs. The length/width ratio of the sperm funnels is about 5-7: 1 in E. albidus s. str., whereas in the other species this ratio is only about 1.5-4: 1 . Furthermore, the penial bulbs in E. albidus s. str. are smaller than in E. moebii and generally smaller than in E. albellus sp. nov., and both specimens of $E$. cf. krumbachi that we examined (Table 3). The main glands (bulbs) in the penial apparati of E. albidus s. str. are in some cases larger but usually about the same size as the surrounding accessory glands, while the bulbs of E. moebii, E. cf. krumbachi, and E. albellus are always clearly larger than the surrounding glands. We also observed a higher variability in the shape of the spermathecae in E. albidus s. str. than in the other species, but this may be due to the fact that we studied a higher number of specimens of E. albidus.

The earlier descriptions of the species already synonymized (i.e., E. constrictus Backlund, E. hortensis Goodrich, and E. humicultor Vejdovský) match our strict definition of

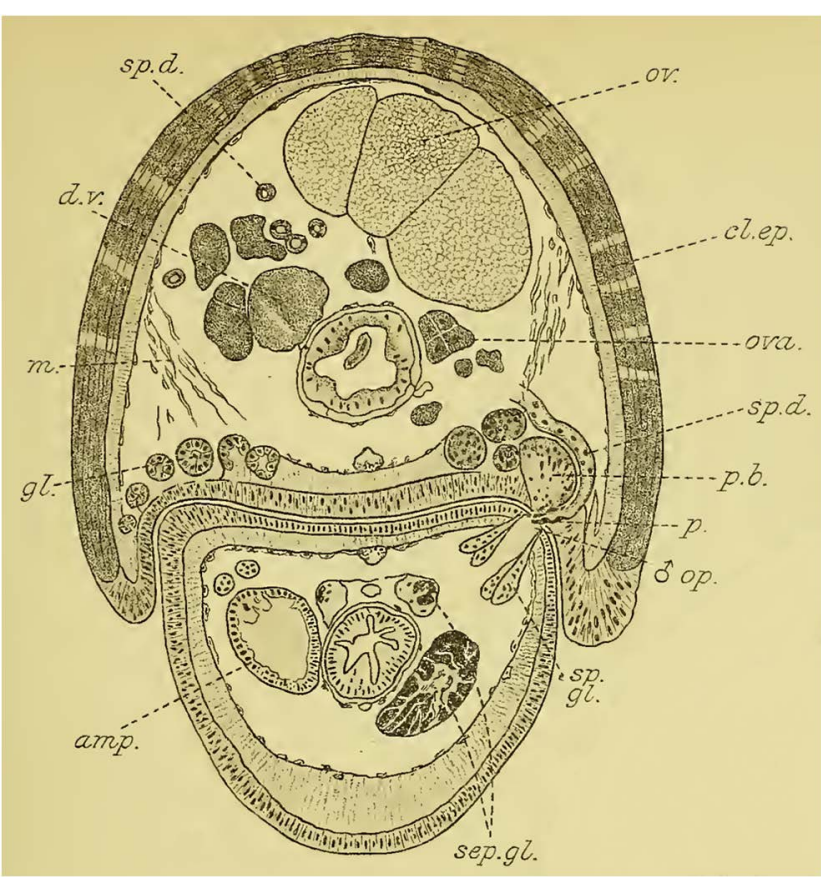

Fig. 8 Enchytraeus pellucidus Friend, 1899, sensu Stirrup (1913), section through two specimens during copulation (reproduced from Stirrup 1913, pl. XLIX, fig. 19)

E. albidus well in most characters. Backlund (1947) described his Enchytraeus constrictus as being distinguished from E. albidus by the deep intersegmental groove between segments IV and V. This character was observed in two out of nine of our specimens of E. albidus s. str., thus it may not be of much taxonomic value. Furthermore, the three synonymous taxa mentioned above were all described from terrestrial habitats, E. constrictus from a pile of manure in Sweden, E. hortensis from a garden in southern England, and E. humicultor from humid, ammonia-rich soils outside Prague in the Czech Republic. The other species we have recognized all have an exclusively marine littoral lifestyle; therefore, we agree with Nielsen and Christensen (1959) and previous authors in regarding E. constrictus, E. hortensis, and $E$. humicultor as junior synonyms of $E$. albidus s. str.

E. pellucidus Friend, 1899, also resembles E. albidus somewhat. This species was originally found in a pile of manure outside Manchester, England, and briefly described as having three-four chaetae per bundle, white color, and vasa deferentia extending back into XX or even XXIV. The chief distinction between this species and E. albidus s. str. is the lack of glands at the spermathecal openings. However, there is no illustration to support this, and the original specimens of E. pellucidus have been lost. The taxonomic status of E. pellucidus thus remains doubtful. In 1913, Stirrup redescribed $E$ pellucidus from a similar habitat (a heap of leafmold near Birmingham, England) and provided several informative illustrations, in particular the one showing a cross section of the genital fields of two specimens during copulation, 
Table 3 Comparison of morphological characters between the species included in this study. Measurements of E. polatdemiri are derived from text and figures in Arslan et al. (2018)

\begin{tabular}{|c|c|c|c|c|c|c|}
\hline $\begin{array}{l}\text { Species (number of } \\
\text { specimens) }\end{array}$ & E. albidus s. str. (9) & E. moebii (6) & $\begin{array}{l}\text { E. albellus sp. nov. } \\
\text { (6) }\end{array}$ & $\begin{array}{l}\text { E. cf. krumbachi } \\
\text { (2) }\end{array}$ & E. sp. 1 (2) & E. polatdemiri \\
\hline Length I-XII & $2.6-3.3 \mathrm{~mm}$ & $2.3-3.8 \mathrm{~mm}$ & $1.6-2.7 \mathrm{~mm}$ & $2.9-3.8 \mathrm{~mm}$ & $1.6-2.2 \mathrm{~mm}$ & N/A \\
\hline Width at XII & $0.57-1.08 \mathrm{~mm}$ & $0.43-0.89 \mathrm{~mm}$ & $0.51-0.72 \mathrm{~mm}$ & $0.40-0.62 \mathrm{~mm}$ & $0.46-0.77 \mathrm{~mm}$ & $0.41-0.58 \mathrm{~mm}$ \\
\hline $\begin{array}{l}\text { Lateral chaetae } \\
\text { preclit.: postclit. }\end{array}$ & $3-4(5):(2) 3$ & $3-4: 2-3$ & $3-4: 2-3(4)$ & $3: 2$ & $3-4: 3$ & $2-3: 2-3$ \\
\hline $\begin{array}{l}\text { Ventral chaetae } \\
\text { preclit.: postclit. }\end{array}$ & $3-5: 2-4$ & $3-4(5): 2-3$ & $3-5: 2-3(4)$ & $3-4: 2$ & $3-4: 3$ & $2-3: 2-3$ \\
\hline Max length & $80-130 \mu \mathrm{m}$ & $60-120 \mu \mathrm{m}$ & $65-115 \mu \mathrm{m}$ & $55-75 \mu \mathrm{m}$ & $125-135 \mu \mathrm{m}$ & $80-110 \mu \mathrm{m}$ \\
\hline $\begin{array}{l}\text { Sperm funnel } \\
\text { length: width }\end{array}$ & $5-7: 1$ & $1.5-3.5: 1$ & $2-4: 1$ & $1.5-2: 1$ (at least) & $\mathrm{N} / \mathrm{O}$ & $5: 1$ \\
\hline $\begin{array}{l}\text { Vas deferens } \\
\text { posteriormost segment }\end{array}$ & XIV-XX & XV-XVI & XVI-XXVIII & XVI-XVIII & $\mathrm{N} / \mathrm{O}$ & XII-XV \\
\hline $\begin{array}{l}\text { Uniform cell wall } \\
\text { thickness }\end{array}$ & Yes & Yes & No & No & $\mathrm{N} / \mathrm{O}$ & Yes \\
\hline Diameter $(\mu \mathrm{m})$ & $30-55$ & $20-25$ & $\begin{array}{l}25-45 \text { (thin wall) } \\
30-65 \text { (thick wall) }\end{array}$ & $\begin{array}{l}15-30 \text { (thin wall) } \\
50-55 \text { (thick wall) }\end{array}$ & $\mathrm{N} / \mathrm{O}$ & $\begin{array}{l}15-30 \\
\text { (wider in ental } \\
\quad \text { part) }\end{array}$ \\
\hline Ciliation throughout & Yes & Yes & Yes & No & $\mathrm{N} / \mathrm{O}$ & Yes \\
\hline Penial bulb diameter & $60-95 \mu \mathrm{m}$ & $110-180 \mu \mathrm{m}$ & $70-120 \mu \mathrm{m}$ & $85-90 \mu \mathrm{m}$ & $\mathrm{N} / \mathrm{O}$ & ca. $100 \mu \mathrm{m}$ \\
\hline Accessory glands & $\begin{array}{l}\text { Smaller or same } \\
\text { size }\end{array}$ & Smaller & Smaller & Smaller & $\mathrm{N} / \mathrm{O}$ & Smaller \\
\hline $\begin{array}{l}\text { Spermathecae with } \\
\text { diverticula }\end{array}$ & In some specimens & No & In some specimens & No & $\mathrm{N} / \mathrm{O}$ & No \\
\hline
\end{tabular}

$\mathrm{N} / \mathrm{O}$ not observed (lack of mature specimens)

where spermathecal glands (“sp. gl.”) are shown near the external opening in the sperm-receiving worm (Fig. 8). Stirrup stated that E. pellucidus indeed lacks the rosette of glands around the pore of the spermatheca, but also that this species does have simple glands along the ectal part of the spermathecal duct. After studying specimens of both E. pellucidus and E. albidus, he concluded that the two cannot be regarded as separate species.

In 1936, Altman described two Enchytraeus species: E. multiannulatus and E. multiannulatoides from Washington State, USA. Both are reminiscent of E. albidus and both were found in terrestrial habitats; E. multiannulatus from decaying organic matter and newspapers near the edge of a salt march, and E. multiannulatoides from a compost with manure. The two species are supposedly separated from E. albidus s. str. and each other by the number of chaetae per bundle (mostly 3 laterally and 5 ventrally in E. multiannulatus; mostly 4 laterally and $4-5$ ventrally in E. multiannulatoides) and number of accessory glands (10 in E. multiannulatus; $18-20$ in E. multiannulatoides) in the genital field, but future studies will be needed to prove their taxonomic status.

E. sabulosus Southern, 1906, described from gravel at the high-water mark in Dublin Bay, Ireland, has also been regarded a synonym of E. albidus (e.g., by Nielsen and Christensen 1959). However, as this species has never more than two-three chaetae per bundle, spermathecae with a thin duct "thickly covered with small glands all along its length", sperm funnels three-four times as long as broad, and vasa deferentia extending backwards to XX but of unknown structure, we consider it separate from E. albidus.

\section{Geographical distribution of genetically verified specimens} Germany, Greenland, Norway, and Sweden in the present study; also recognized from Ireland and Northern Spain (Arslan et al. 2018) (see "Habitat" below), and Canada (as COI barcodes among BOLD records). This species is represented in BOLD by BIN: AAN7506. Morphologically identified specimens (including species placed as synonyms above) indicate a wider range, but specimens from these localities have not been verified as belonging to E. albidus s. str. as defined here.

Habitat Seashores (above or below the high-water mark), salt marshes, and terrestrial; typically supralittoral, in decomposing seaweed and algae, or in decomposing organic material on land. Occasionally in freshwater. Worms can be kept for years in laboratory cultures.

The records from Ireland and Northern Spain in Arslan et al. (2018) were from lab cultures maintained by Dr. Rüdiger M. Schmelz since the original collection in the field (1995, Bull Island, Dublin, and 2011, Las Amorosas, A 
Coruña, respectively). According to Schmelz (pers. comm.), the Irish site was upper littoral, a sandy soil flooded at highest tide, and the Amorosas site was slightly more terrestrial, i.e., turf of a thrift species (Armeria pubigera) on solid granite, but within the reach of sea spray. This shows that wild strains of this species may live in a lab regardless of their original habitat, i.e., with or without access to salt from the sea.

\section{Enchytraeus moebii (Michaelsen, 1885) (Figs. 9-10)}

Archenchytraeus möbii Michaelsen, 1885: pp. 237-239.

Enchytraeus möbii; Michaelsen 1886: pp. 1-52, pl. I, figs. $1-16$, pl. II, figs. $1-7$, pl. III, figs. 1-10.

E. albidus partim; Nielsen and Christensen 1959: pp. 9192, figs. 95-100.

E. albidus "clade A"; Erséus and Gustafsson 2009.

E. albidus; Christensen and Glenner 2010: table 1.

E. albidus "EA-DK"; Arslan et al. 2018.

Material examined SMNH 172878-172880 (CE965, CE972, and CE973), SMNH 172883 (CE2789), and SNHM 172885 (CE2966), 5 specimens from Swedish seashores; SMNH 172876 (CE1686), 1 specimen from algal compost in Galicia, Spain. All specimens sexually mature and COI barcoded. For more details, including GenBank accession numbers for genetic data, see Table 1 .

Diagnosis Several chaetal bundles with more than three chaetae; sperm funnels 1.5-3.5 times longer than wide; vasa deferentia with uniform cell wall thickness; penial bulbs larger than accessory glands; spermathecae without diverticula.
External characters Color white. Length of first 17-35 segments, > 3-9 mm (fixed, amputated specimens); first 12 segments (anterior end to clitellum) $2.3-3.8 \mathrm{~mm}$ long; width at clitellum $0.43-0.89 \mathrm{~mm}$. Chaetae straight or slightly curved. Lateral bundles with 3-4 chaetae anterior to clitellum, 2 in XII, 2-3 chaetae in postclitellar segments. Ventral bundles with 3-4(5) chaetae anterior to clitellum, missing in XII, 2-3 chaetae in postclitellar segments. Chaetae longest in ventral bundles anterior and posterior to XII, measuring $60-120$ by $5-$ $8 \mu \mathrm{m}$. Clitellum extending over XII-1/2XIII or $-3 / 4$ XIII. Head pore not observed. Epidermis with transverse rows of gland cells.

Internal characters Coelomocytes numerous, $10-15 \mu \mathrm{m}$ long, round, oval, or spindle-shaped, granulated and with distinct nucleus. Paired pharyngeal glands present in IV, V, and VI. All pairs with secondary lobes, first and second pairs possibly with narrow dorsal connection, third pair not connected. Esophageal appendages (peptonephridia) extending from dorsal wall of esophagus in III. Dorsal vessel seemingly originating in XIV or XV. Nephridia in 6/7-9/10 and from $13 / 14$ to $21 / 22$ at least, about $80 \mu \mathrm{m}$ long, anteseptale consisting of funnel only, postseptale elongate ovoid, with efferent duct originating posteroventrally. Brain posterior margin straight or slightly indented.

Male genitalia paired. Testes in XI, paired, each enclosed in a sac and extending forwards into X. Sperm funnels in XI, 295-420 $\mu \mathrm{m}$ long, 120-265 $\mu \mathrm{m}$ wide at the widest point, making them about 1.5-3.5 times longer than wide, funnels tapering towards vasa deferentia. Vasa irregularly coiled in XIIXVI, of about uniform width $(20-25 \mu \mathrm{m})$ throughout, with 2.5-5 $\mu \mathrm{m}$ thick wall. Vasa ciliated, without conspicuous
Fig. 9 Enchytraeus moebii a male copulatory apparatus. b-c Spermathecae. ag accessory glands, ed ectal duct, eg ectal gland, $m u$ musculature, $p b$ penial bulb, $s a$ spermathecal ampulla, $s m$ sperm, $v d$ vas deferens. Scale bar $100 \mu \mathrm{m}$

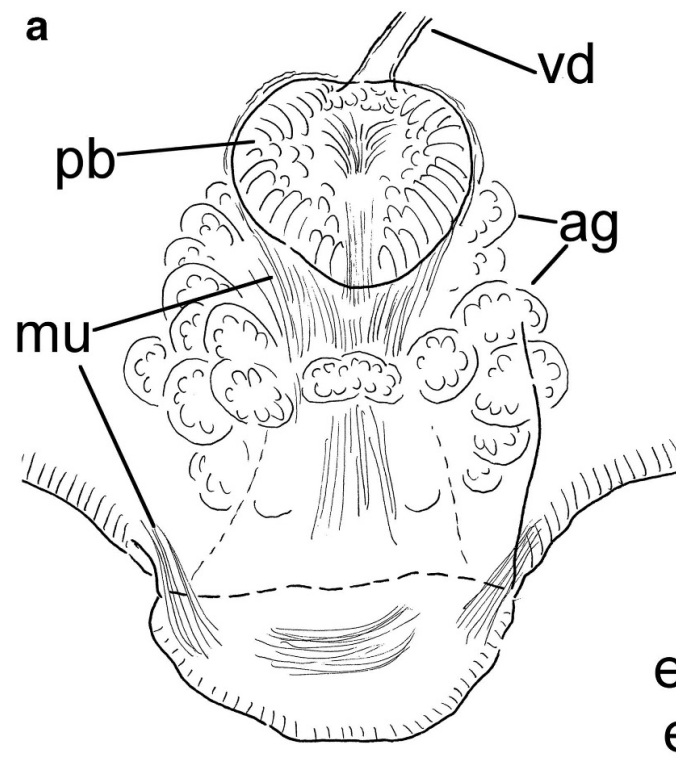

b
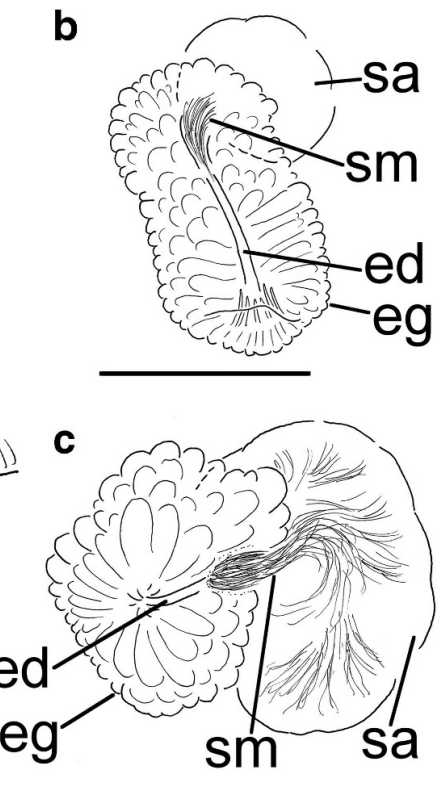
musculature. Vasa seemingly not penetrating penial bulbs. Ventral surface of XII with invaginations creating two recesses with overhanging lips. Penial bulbs compact, round, 110 $180 \mu \mathrm{m}$ in diameter, sheathed with muscles, and surrounded by accessory glands much smaller in size (Fig. 9a). Ovaries in XII. About one to five mature eggs present at a time.

Spermathecae in V. Ectal pore at lateral line or just above. Ectal duct short to moderately long, covered with gland cells and abruptly widening into sac-like ampulla (Fig. 9b-c). Ampulla usually rounded, ental connection with esophagus uncertain, no observed diverticulum. Sperm in lumen of ampulla and sometimes in ectal duct; heads of spermatozoa embedded in wall of ental part of ampulla, forming aggregates. Spermathecae 205-225 $\mu \mathrm{m}$ long, 80-90 $\mu \mathrm{m}$ wide at widest part of ampulla. Gland cells surrounding ectal duct, forming compact mass $80-125 \mu \mathrm{m}$ in diameter at its widest part; glands seemingly extending along entire duct (but see Fig. 10, and "Remarks"). No obvious midventral subneural glands observed.

Remarks Our specimens agree for the most part with Michaelsen's extended description of E. moebii (1886), but they have on average fewer chaetae per bundle and sometimes shorter sperm funnels. Our material is identified as this species primarily based on the combination of penial bulbs being larger than the accessory glands, and spermathecae having duct and ampulla of equal length but without diverticula. Obviously using sectioned material, Michaelsen (1886) illustrated a short inner part of the spermathecal duct as being devoid of gland cells (Fig. 10). This could not be discerned in our slide-mounted specimens, but it may be a general feature of this taxon.

E. moebii was synonymized with E. albidus by Nielsen and Christensen (1959), but the molecular data in this study support considering the two as separate species. Furthermore, unlike E. moebii, E. albidus s. str. has penial bulbs of about the same size as the accessory glands, sperm funnels quite elongate in relation to their width, and spermathecae with diverticula, making it possible to distinguish these two species morphologically.

E. moebii is morphologically most similar to E. albellus $\mathrm{sp}$. nov. (described below), and these two species do not seem to be distinguishable with regard to chaetal size and number, or sperm funnel proportions (Table 3). Both species have penial bulbs that are much larger than the surrounding accessory glands (compare Figs. 9a, 10, and 11d). However, the spermathecae of E. moebii lack diverticula, whereas those of $E$. albellus usually have at least one dorsal diverticulum. Furthermore, the vasa deferentia of E. moebii have rather uniform width and wall thickness, whereas the middle portion of the E. albellus vasa is wider and has thicker walls than the ental and ectal portions. The dimensional contrasts between the different sections of the vasa deferentia are even more prominent in our specimens of E. cf. krumbachi (described below), which also makes the latter species distinguishable from E. moebii.

E. moebii was originally described from decomposing seaweed in the Kiel Bay, Baltic Sea. Our specimens were partly from the Baltic Sea (sites around the island of Öland), but we also found the same lineage along a long stretch of the NorthEast Atlantic coast. We have decided not to designate any neotype for this species as we do not have material from the type locality.

Geographical distribution of genetically verified specimens Norway (including a BOLD record from Oslofjorden, NOENC236-15), Sweden, and Spain in the present study; also recognized from Denmark (GenBank GU453370; see Christensen and Glenner 2010). This species is represented in BOLD by BIN: AAM5959. The type locality is on the Baltic coast of Germany.

Habitat Seashores and salt marshes, but also in the intertidal zone; typically in decomposing seaweed and algae.

\section{Enchytraeus albellus Klinth, Erséus and Rota, sp. nov. (Fig. 11)}

Holotype SMNH Type Collection 9123 (CE6100), mature specimen, whole-mounted on a slide, from Färlevfjorden (inner end of Gullmarfjorden), west coast of Sweden, 27 May 2009, leg. C. Erséus, A. Ansebo, and M. Johansson. COI barcode: GenBank MK266873; for more details, including GenBank accession numbers for additional genetic data, see Table 1. Figures 11a-e are illustrations of this specimen.

Paratypes All from type locality, mature, and whole-mounted on slides. SMNH Type Collection 9124-9126 (CE61016103); for more details, including GenBank or BOLD accession numbers for genetic data, see Table 1.

Other material studied SMNH 172888-172889 (SM144 and SM189) two whole-mounted, mature specimens from a sandy, stony beach, Qeqertarsuaq town, Greenland; for more details, including GenBank numbers for genetic data, see Table 1.

Etymology Latin albellus, diminutive of albus, i.e., whitish.

Diagnosis Several chaetal bundles with more than three chaetae; sperm funnels 2-4 times longer than wide; vasa deferentia tripartite: ental and ectal sections thin-walled, middle section thick-walled, all parts ciliated; penial bulbs larger than accessory glands; spermathecae sometimes with one diverticulum.

External characters Color white. Length of first 21-54 segments $>3-10 \mathrm{~mm}$ (fixed, amputated specimens); first 12 
Fig. 10 Enchytraeus moebii 3 male apparatus and 7 spermatheca; from Michaelsen (1886; pl. II figs. 3., 7.)

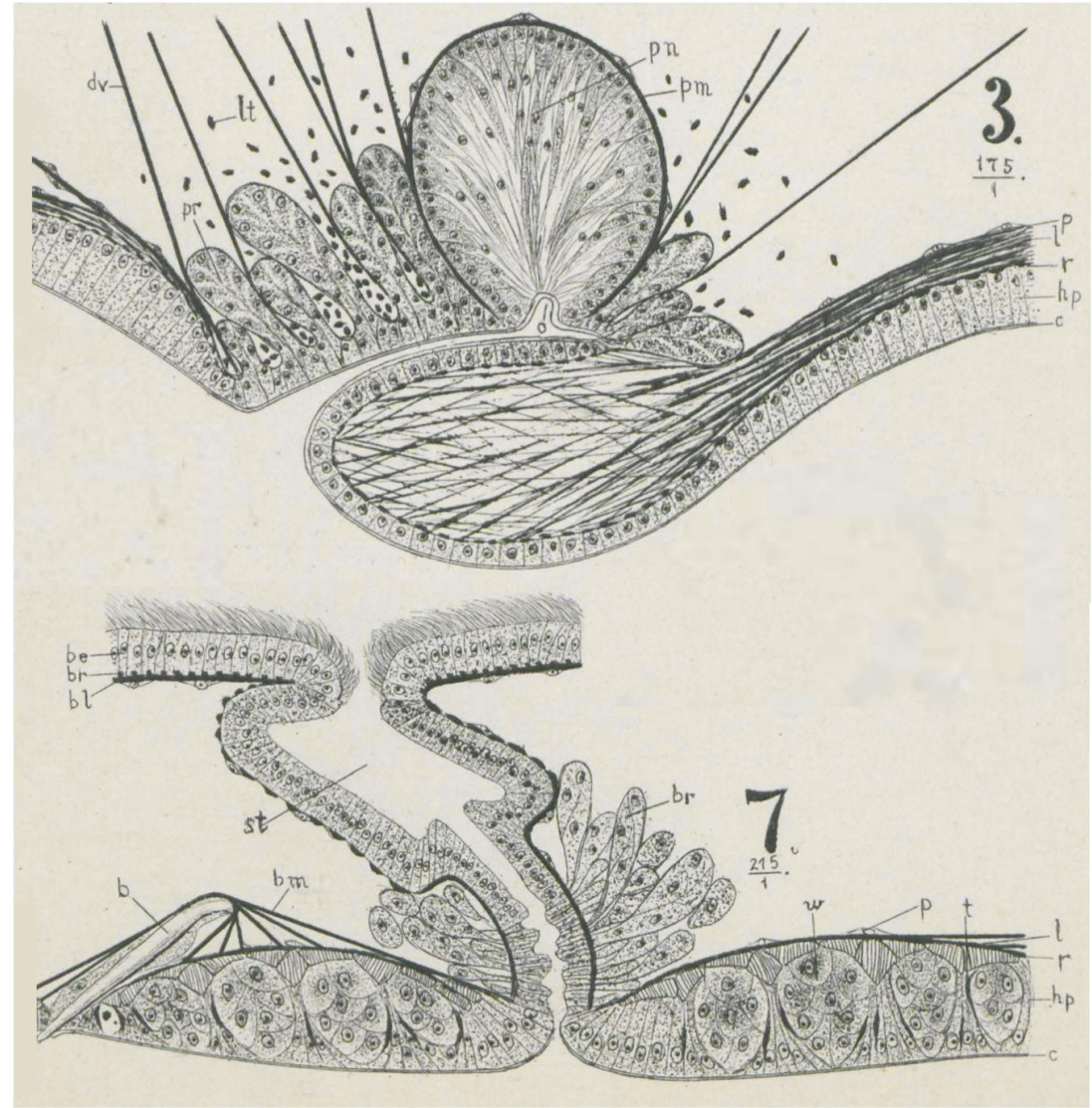

segments (anterior end to clitellum) 1.6-2.7 mm long; width at clitellum $0.51-0.72 \mathrm{~mm}$. Chaetae straight or slightly curved. Lateral bundles with 3-4 chaetae anterior to clitellum, 0-2 in XII, 2-3(4) chaetae in postclitellar segments. Ventral bundles with 3-5 chaetae anterior to clitellum, missing in XII, 2-3(4) chaetae in postclitellar segments. Chaetae longest in ventral preclitellar bundles (IV-XI) and some lateral bundles close to XII, measuring $65-115$ by $5-8 \mu \mathrm{m}$. Clitellum extending over XII- $1 / 2$ XIII or $-3 / 4$ XIII. Head pore between prostomium and peristomium. Epidermis with transverse rows of gland cells.

Internal characters Coelomocytes numerous, 10-25 $\mu \mathrm{m}$ long, round, oval, or spindle-shaped, granulated and with distinct nucleus. Paired pharyngeal glands present in IV, V, and VI. All pairs with secondary lobes, dorsal connections between the pairs uncertain. Esophageal appendages (peptonephridia) extending from dorsal wall of esophagus in III. Dorsal vessel originating in XIV or XV. Nephridia in 6/7-9/10 and from 13/ 14 to $14 / 15$ at least, about $75-80 \mu \mathrm{m}$ long, anteseptale with funnel only, postseptale oval tapering into posteroventral efferent duct, in one specimen nephridia observed also from 30/ 31 to $49 / 50$. Brain truncate posteriorly.

Male genitalia paired. Testes in XI, each surrounded by masses of cells at different stages of spermatogenesis within peritoneal sac; testis sacs bulging into IX. Sperm funnels in
XI, 400-530 $\mu \mathrm{m}$ long, 135-235 $\mu \mathrm{m}$ widest, making them about 2-4 times longer than wide, funnels tapering towards vasa deferentia (Fig. 11a). Vasa irregularly coiled in XIIXXVIII, tripartite, ental and ectal parts thinner and thinwalled, 25-35(45) $\mu \mathrm{m}$ wide with $2.5-5 \mu \mathrm{m}$ thick wall, middle part wider $(30-45(65) \mu \mathrm{m})$ with thicker wall $(10-20 \mu \mathrm{m})$ (Figs. 11b-c). All parts ciliated, without conspicuous musculature. No abrupt transition between thin- and thick-walled parts and the different parts seem indistinguishable in some specimens, possibly becoming clearer with maturation. Vasa seemingly not penetrating penial bulbs. Ventral surface of XII with invaginations creating two recesses with overhanging lips. Penial bulbs compact, round, $70-120 \mu \mathrm{m}$ in diameter, surrounded by accessory glands much smaller in size (Fig. 11d). Ovaries in XII. About one to four mature eggs present at a time.

Spermathecae in V. Pore at lateral line. Ectal duct short, abruptly widening into sac-like ampulla (Fig. 11e) entally connected with lateral side of esophagus. Ampulla usually with irregular outline, sometimes with one, usually dorsal diverticulum. Sperm in lumen of ampulla, heads of spermatozoa embedded in wall of ental part of ampulla, forming aggre-

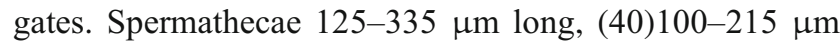
wide at widest part of ampulla. Gland cells surrounding ectal duct, forming compact mass $65-120 \mu \mathrm{m}$ in diameter at its 
Fig. 11 Enchytraeus albellus Klinth, Erséus and Rota, sp. nov., holotype. a Sperm funnel. b Transverse section comparing thin- and thick-walled portions of vas deferens. c Longitudinal section comparing thin- and thickwalled portions of vas deferens. $\mathbf{d}$ Male apparatus. e Spermatheca. ag accessory glands, $e d$ ectal duct, eg ectal gland, $m u$ musculature, $p b$ penial bulb, $s a$ spermathecal ampulla, $s f$ sperm funnel, $s m$ sperm, $v d$ vas deferens. Scale bars $100 \mu \mathrm{m}$
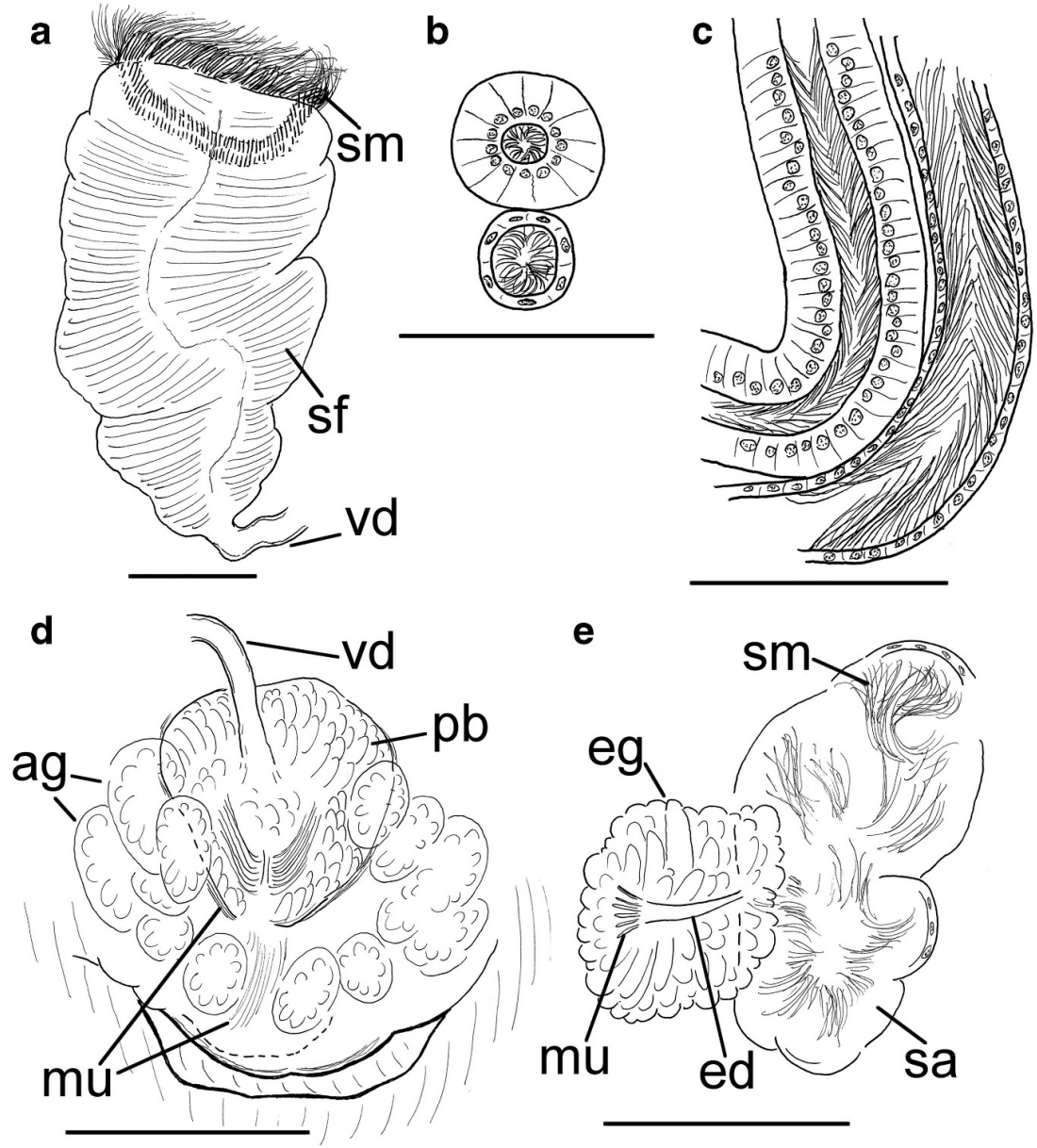

e

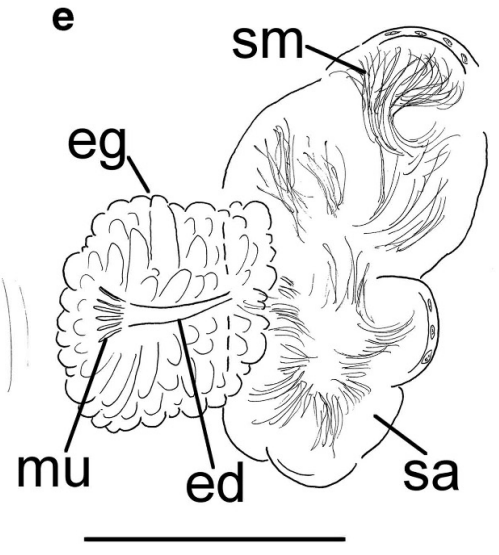

widest part; in some (possibly all) specimens, a short, ental part of duct not covered by these cells. No obvious midventral subneural glands observed.

Remarks Despite a thorough literature search, we have been unable to locate any previous reference to, or description of, the E. albellus morphotype. E. albellus is genetically well separated from our specimens of E. albidus s. str. in both the COI (Fig. 3a) and ITS2 (Fig. 3c) regions. In addition, there are several morphological characters that distinguish E. albellus from all other species in the E. albidus species complex.

As noted above, E. albellus is morphologically similar to E. albidus s. str. and to our E. cf. krumbachi in having long, tripartite, and partly very wide and thick-walled vasa deferentia, which occupy several segments beyond the clitellum; E. moebii also has long vasa, but in this species the vasa are uniformly narrow.

E. albellus differs from E. albidus s. str. in the following characters: (1) the separation of the vasa into thick- and thinwalled sections is not as clear-cut in E. albidus as in E. albellus; (2) the penial bulbs are not much larger than the accessory glands in E. albidus, but the penial bulbs are distinctly larger than the accessory glands in E. albellus (compare
Figs. 6 and 11d); and (3) the sperm funnels are 5-7 times longer than wide in E. albidus, compared to 2-4 times for E. albellus.

E. albellus can be separated from E. cf. krumbachi in having a dorsal diverticulum on the spermatheca, cilia in all parts of the vasa, and more than two chaetae per bundle in postclitellar segments (Table 3 ).

Geographical distribution Sweden, Norway, and Greenland. This species is represented in BOLD by BINs: AAT8961 and ACV8067.

Habitat In seashores, both above and below the high-water line, and with a clear tendency to go lower into the intertidal zone than E. albidus and E. moebii; occurs in decaying organic material on beaches, but is common also in rather clean intertidal sand and gravel.

\section{Enchytraeus cf. krumbachi (Čejka, 1913) (Fig. 12)}

?Litorea krumbachi Čejka, 1913: pp. 145-151, figs. 1-10.

?E. albidus partim; Lasserre and Erséus 1976: pp. 452453. 
E. albidus "clade C"; Erséus and Gustafsson 2009.

Material examined SMNH 172891-172892 (CE1684 and CE1689), two sexually mature and COI-barcoded specimens from algal compost in Galicia, Spain. For more details, including GenBank accession numbers for genetic data, see Table 1.

Diagnosis A few chaetal bundles with more than three chaetae; sperm funnels at least 1.5-2 times longer than wide; vasa deferentia tripartite, ental and ectal sections thin-walled, middle section thick-walled and lacking ciliation; penial bulbs larger than accessory glands; spermathecae without diverticula.

External characters Color white. Length of first 16-19 segments $>2 \mathrm{~mm}$ (fixed, amputated specimens); first $12 \mathrm{seg}$ ments (anterior end to clitellum) 2.9-3.8 mm long; width at clitellum $0.40-0.62 \mathrm{~mm}$. Chaetae straight or slightly curved. Lateral bundles with three chaetae anterior to clitellum, two chaetae in XII and postclitellar segments. Ventral bundles with three-four chaetae anterior to clitellum, missing in XII, two chaetae in postclitellar segments. Chaetae longest in preclitellar ventral bundles (VIII-XI), 55-75 $\mu \mathrm{m}$ long, about $5 \mu \mathrm{m}$ wide. Clitellum extending over XII-3/4XIII. Head pore not observed. Epidermis with transverse rows of gland cells.
Internal characters Coelomocytes numerous, $10-15 \mu \mathrm{m}$ long, round, oval, or spindle-shaped, granulated and with distinct nucleus. Paired pharyngeal glands present in IV, V, and VI. All pairs seemingly connected dorsally and possessing secondary lobes. Esophageal appendages (peptonephridia) extending from dorsal wall of esophagus in III. Origin of dorsal vessel not observed. Nephridia observed in 6/7-9/10, about $110 \mu \mathrm{m}$ long, with oval postseptale tapering into posteroventral efferent duct. Brain truncate posteriorly.

Male genitalia paired. Testes in XI, paired, each enclosed in sac containing different stages of spermatogenesis; sacs extending forwards into IX. Sperm funnels at least 215-305 $\mu \mathrm{m}$ long, $135-160 \mu \mathrm{m}$ wide at the widest point, making them at least 1.5-2 times longer than wide, tapering towards vasa deferentia. Vasa irregularly coiled in XII-XVIII, tripartite, ental and ectal portions thinner, $15-30 \mu \mathrm{m}$ wide with $2.5-5 \mu \mathrm{m}$ thick wall, widening to thicker mid portion, $50-55 \mu \mathrm{m}$ wide with $15 \mu \mathrm{m}$ thick wall (Fig. 12a). The transition between portions gradual, but with an abrupt change in the thickness of the duct wall; ciliation only in parts with thin wall. All parts lacking conspicuous musculature. Ventral surface of XII with invaginations creating two recesses with overhanging lips. Penial bulbs compact, round, $85-90 \mu \mathrm{m}$ in diameter, not pierced by vasa, surrounded by accessory glands of smaller size (Fig. 12b). Ovaries in XII. About one to five mature eggs present at a time.

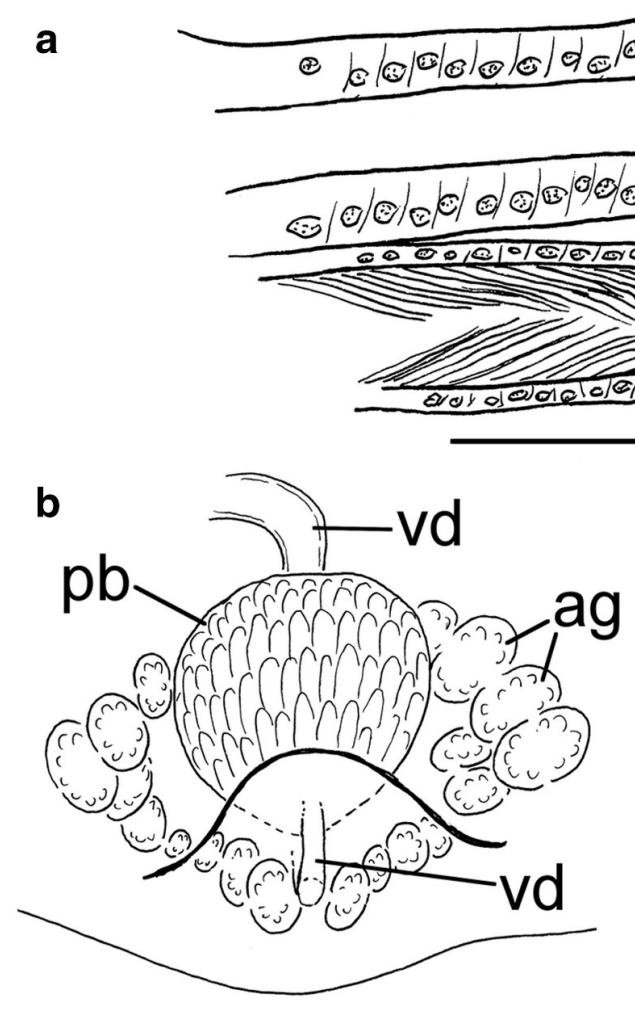

Fig. 12 Enchytraeus cf. krumbachi a vas deferens, showing the transition between the thin- and thick-walled portions; note the lack of cilia inside the thick-walled part. b Male copulatory apparatus. c Spermatheca. ag

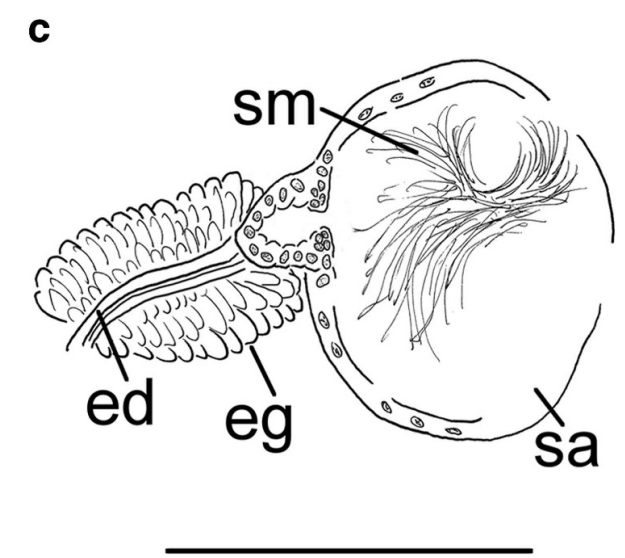

accessory gland, ed ectal duct, eg ectal gland, $p b$ penial bulb, $s a$ spermathecal ampulla, $s m$ sperm, $v d$ vas deferens. Scale bars $100 \mu \mathrm{m}$ 
Spermathecae in V. Ectal pore at lateral line. Ectal duct thin, entally opening into a small, rounded chamber, distinctly set off from round ampulla; ampulla of similar length as entire duct (Fig. 12c). Ampulla round, without diverticula, connected to lateral side of esophagus. Sperm in lumen of ampulla. Spermathecae 155-180 $\mu \mathrm{m}$ long, 95-125 $\mu \mathrm{m}$ wide at widest part of ampulla. Gland cells surrounding ectal duct, forming compact mass $60-65 \mu \mathrm{m}$ in diameter at its widest part; small chamber devoid of gland cells. No obvious midventral subneural glands observed.

Remarks Our association of this species with the Mediterranean L. krumbachi Čejka, 1913, from a beach in Rovinj (Croatia), is largely based on the tripartition of the vasa deferentia. The three parts have different widths and wall thicknesses, and cilia are absent in the middle, thickened, tracts, conforming with Čejka's observation. Similarly, Lasserre and Erséus (1976, plate 1C) showed a cross section of the thick-walled, but unciliated, part of a vas deferens in their Bermudian form of "E. albidus" (see also below). We observed that the vasa deferentia change in width over their length also in E. albidus s. str. and E. albellus sp. nov. In E. albidus s. str., they gradually (and slightly) widen from the ental to the middle part and then taper ectally, without any clear differentiation in wall thickness between the parts. In $E$. albellus, the difference in width between the ental, middle, and ectal parts is not as distinct as in our E. cf. krumbachi, but the middle part clearly has a thicker duct wall than the ental and ectal parts. However, E. albellus has cilia all along the vas' walls, and spermathecae with diverticula, two features distinguishing it from E. cf. krumbachi.

Nevertheless, there are some morphological discrepancies between our Galician material and Čejka's species. First, our form has fewer postclitellar chaetae per bundle; Čejka's (1913) form had three chaetae in lateral, four chaetae in ventral bundles. Second, in a horizontal section of segment V (ibid., fig. 9), Čejka did not observe any separate chambers at the inner end of the spermathecal ducts (cf. our Fig. 12), although, in the same figure, the spermathecal ampullae were shown as barely wider than the glandular ducts, and his specimen may have been in a stage, where such chambers were still undeveloped.

The combination of the distinctly separated parts of the vasa deferentia, latitude of collection, and the adiverticulate spermathecae prompted us to denote our species as $E$. cf. krumbachi. And besides, based on the morphological variation within the E. albidus complex revealed here, and the more stringent definition of E. albidus proposed above, the proposed synonymization of E. krumbachi with E. albidus (see Lasserre and Erséus 1976) does not seem to be justified. However, it would be premature to formally attach the name E. krumbachi (without "cf.") to our Galician specimens, considering that (1) we have no access to topotypes of the Adriatic
E. krumbachi, (2) the number of postclitellar chaetae per bundle are fewer in our specimens than in the original description, and (3) additional forms within the E. albidus complex with the distinctly tripartite vasa deferentia are known from seashores of the North Atlantic/Mediterranean area; however, these forms have not been described in sufficient detail to establish whether or not our Galician specimens are conspecific with any of these proposed species.

There are at least three other literature reports of white worms with bi- or tripartite vasa deferentia of the kind described here. In 1874, Verrill described the species H. littoralis from the coast of Massachusetts (USA), in the Northwestern Atlantic. His brief morphological description (in Verrill and Smith 1874: 329-330) was later amended by Smith (1895), who transferred the species to Enchytraeus and described a long vas deferens with expanding thickness going from quite thin to one fifth the diameter of the entire worm in that region. Due to the pronounced thickening of the vasa deferentia, we do not consider E. littoralis as a junior synonym of E. albidus, as suggested by Michaelsen (1900). Furthermore, we had no access to topotypical material of E. littoralis, and thus, we cannot assess whether these two species are similar in other characters.

As noted above, Lasserre and Erséus (1976) referred to worms found on subtropical Bermuda, i.e., about $1200 \mathrm{~km}$ SSE of the type locality of E. littoralis, as E. albidus. The Bermudian worms also had massive outer parts of the vasa deferentia (op.cit.: pl. 1C): the latter were $65-70 \mu \mathrm{m}$ wide, at least one fifth of the total body diameter, and with 20-25 $\mu \mathrm{m}$ thick walls. These measurements match rather well with the ones we observed for both E. cf. krumbachi (up to $55 \mu \mathrm{m}$ wide, wall up to ca. $15 \mu \mathrm{m}$ thick) and E. albellus (up to $65 \mu \mathrm{m}$ wide, wall up to $20 \mu \mathrm{m}$ thick). Lasserre and Erséus did not provide a complete morphological description, and we have neither new morphological nor any genetic data for the Bermudian form. Nevertheless, with regard to the similarities in the vasa deferentia, we cannot rule out the possibility that this form was conspecific to one of the two aforementioned taxa. If so, E. cf. krumbachi is more likely to be conspecific with the Bermudian specimens, as its latitudinal distribution is more similar. By contrast, the distribution of E. albellus extends into the High Arctic, which may indicate that this species is better adapted to a colder environment.

The third report is the description of Enchytraeus mediterraneus Michaelsen, 1926 from the coast of Tunisia. In this species, the width of the vas' thick portion measured up to $85 \mu \mathrm{m}$. However, spermathecal ectal glands are absent in E. mediterraneus but present in our Galician worms (see more under "Remarks" to Enchytraeus sp. 1); we therefore do not consider our Galician specimens to be conspecific with E. mediterraneus.

The Galician E. cf. krumbachi was recovered as the sister species of Enchytraeus sp. 1 (see Fig. 2) from the Aegean Sea 
in the present molecular study, suggesting that the two represent a southern lineage (as opposed to the northern group of E. albidus, E. albellus, and $E$ moebii).

Geographical distribution and habitat Enchytraeus cf. krumbachi has been genetically identified from Spain only (present material). Čejka's (1913) original material of E. krumbachi was from a seashore in Croatia, while our Spanish worms come from an algal compost.

\section{Enchytraeus sp. 1}

Material examined SMNH 172893-172894 (CE4859CE4860), two half mature specimens from Skopelos Island, Aegean Sea, Greece. For information on voucher collection locality and GenBank accession numbers, see Table 1. Skopelos, Perivouli beach, NE of Glossa, $39^{\circ} 11.84^{\prime} \mathrm{N}, 023^{\circ}$ 36.90' E, in high intertidal sand, leg. C. Erséus, 21 Aug 2008.

External characters Color white. Length of first 28-45 segments > 4-8.4 mm (fixed, amputated specimens); first 12 segments (anterior end to clitellum) 1.6-2.2 mm long; width at clitellum $0.46-0.77 \mathrm{~mm}$. Chaetae straight or slightly curved entally. Lateral and ventral bundles with three-four chaetae anterior to clitellum, three chaetae in postclitellar segments. Chaetae longest in preclitellar ventral bundles (VIII-XI) measuring $125-135$ by about $10 \mu \mathrm{m}$. Clitellum not developed. Head pore between prostomium and peristomium. Epidermis with transverse rows of gland cells.

Internal characters Coelomocytes about $15 \mu \mathrm{m}$ long, round, oval or spindle-shaped, granulated and with distinct nucleus. Paired pharyngeal glands present in IV, V, and VI. All pairs converging dorsally, first pair small, second pair largest. Esophageal appendages (peptonephridia) extending from dorsal wall of esophagus in III. Dorsal vessel seemingly originating in XV. Nephridia difficult to discern but pores of nephridial efferent ducts possibly observed in 5/6-7/8, and 8/9 and in some postclitellar segments, shape uncertain. Brain longer than wide, posterior margin straight.

Male genitalia paired. Developing testes in XI, penial bulbs and ovaries in XII. Rudimentary spermathecae in V.

Remarks Although this Aegean Sea species is yet unidentified, and no details about its genital characters are known, the DNA-based phylogeny (Fig. 2) suggests that it is likely to be part of the E. albidus complex, and more closely related to $E$. cf. krumbachi than to the other species included here. Geographically, the record of $E$. sp. 1 is closest to the type locality of E. krumbachi in the Adriatic Sea (Čejka 1913).

According to the original description (op.cit.), E. krumbachi has lateral bundles with three chaetae and ventral bundles with four chaetae. Both our specimens of $E$. sp. 1 have three chaetae in all postclitellar bundles, both ventrally and laterally, but these differences may be due to the fact that our specimens are not mature.

Interestingly, the size of the chaetae in $E$. sp. 1 is the largest recorded in this study and recalls that of E. mediterraneus, described by Michaelsen (1926) from Posidonia detritus in Djerba (Southern Tunisia). E. mediterraneus is a very large worm (26 mm long, with 90 segments), with 3-4 chaetae in all bundles (each chaeta measuring 150 by $10 \mu \mathrm{m}$ at midbody), pharyngeal glands dorsally fused and with large ventral lobes, dorsal vessel from XVIII, sperm funnels three times longer than wide, vas deferens reaching XXI and with diameter measuring $40-50 \mu \mathrm{m}$ entally, $85 \mu \mathrm{m}$ along the mid portion and $27 \mu \mathrm{m}$ near the male apparatus, spermathecal ampulla onionshaped with some small indistinct ectal swellings, ectal duct as long as ampulla but much thinner, and completely devoid of glands. As our specimens are immature, most of these characters cannot be compared to the description of E. mediterraneus. We therefore prefer to keep this Aegean material unidentified until fresh material of $E$. mediterraneus can be examined and barcoded.

Distribution and habitat Known only from the high intertidal of a beach on the island of Skopelos, Greece. The sand at this site appeared poor in decaying organic material.

\section{Discussion}

\section{Molecular data: species delimitation and phylogeny}

From the molecular evidence presented here, we conclude that lineages referred to as E. albidus s. str, E. albellus sp. nov., E. moebii, E. cf. krumbachi, and E. sp. 1, in the E. albidus complex, represent five distinct species. All of them are well supported in the species delimitation analyses in BPP, a method that has been used also in several other studies on clitellate worms (e.g., Martinsson and Erséus 2017, 2018a, b; Martin et al. 2018; Taheri et.al. 2018) and has proven to be a useful tool to delimit species in closely related lineages.

The species tree based on both mitochondrial and nuclear markers analyzed in this study (Fig. 2) supports the monophyly of the E. albidus species complex (represented by the morphospecies E. albidus s. lat. and E. polatdemiri), as well as of the five individual species here identified within E. albidus s. lat. Close relationships within this group were also advocated by Arslan et al. (2018), although the latter authors, in their molecular analyses, only included samples which in our study have been genetically identified as E. albidus s. str. and E. moebii. Arslan et al. recovered E. polatdemiri as sister to E. albidus s. lat., but they addressed the alternative possibility of it being derived from within the latter assemblage. Our study, with a larger sample of taxa but without support for 
the sister group hypothesis, does not exclude either possibility. Moreover, E. polatdemiri is not the only albidus-like taxon described from slightly saline lakes. Enchytraeus przewalskii Hrabě, 1935, and Enchytraeus issykkulensis Hrabě, 1935 are two such species from Lake Issyk-Kul in Kyrgyzstan (Central Asia), for which, however, no genetic data are available; see also Arslan et al. (2018).

\section{Morphology}

This study has established four morphologically separate species, all initially identified as E. albidus Henle, 1837, plus a fifth (genetically well supported) species, Enchytraeus sp. 1, for which our morphological knowledge still is limited. E. polatdemiri Arslan and Timm, 2018, was already recognized as separate from E. albidus s. lat. by its original authors (in Arslan et al. 2018), but we have considered it as a part of the E. albidus species complex. In the present study, it comes out as sister to E. albidus s. lat., but our sample of taxa is likely to be a mere part of a larger lineage of very similar species.

We observed a few morphological differences, particularly in the sperm funnels, vasa deferentia, spermathecal diverticula, and penial apparatus, which allowed us to associate some of our genetically distinct species with taxa previously synonymized with E. albidus. However, in most characters, such as body size, brain shape, origin of the dorsal vessel, and the number of chaetae per bundle, E. albidus s. str., E. moebii, $E$. cf. krumbachi, and E. albellus sp. nov. overlap. We here anchored E. albidus in our phylogeny by neotypification, which is supported by both morphology and ecology (see below). We were also able to associate some of our specimens with the older names E. moebii and E. cf. krumbachi. Finally, we propose a new name, E. albellus, for a previously undescribed group of worms in this complex. All these taxa are discussed in detail above, with additional details given in Table 3. However, it is possible that a further examination of specimens from additional sampling localities will reveal that more of the characters are indeed overlapping, making these species difficult to distinguish from each other without the aid of genetic data.

All these species (as well as E. polatdemiri) have a peculiar organization of the genital field, including a ventral invagination. The latter seems to be used to facilitate the transfer of sperm to the spermathecae during copulation (see Fig. 8). In addition, this region is equipped with accessory glands whose excretion could also be important during copulation. We noted some differences in the size of the penial bulbs relative to these accessory glands, where E. albidus s. str. seems to have penial bulbs of about the same size or smaller than the surrounding glands, whereas E. moebii, E. albellus, and E. cf. krumbachi have bulbs that are clearly larger than the accessory glands. This difference is difficult to properly measure on whole-mounted material, and cross-sectioned material from a larger sample would be required to ascertain the taxonomical importance of this character.

The size and thickness of the vasa deferentia may also be taxonomically important in this group. In all species except E. moebii, we found that the vasa deferentia change in appearance throughout their length, with some parts being larger and more thick-walled than others. In E. albidus s. str., we observed parts with thin walls and parts with thick walls, but these parts did not differ significantly in total (external) diameter. In E. albellus and $E$. cf. krumbachi, the thick-walled parts were considerably wider than the thin-walled parts. As far as we could establish, the muscular strength did not differ between the different parts of the vasa in any of the species. However, we did note that our specimens of E. cf. krumbachi lacked ciliation in the thick-walled parts, unlike the other species where all parts were ciliated. We do not know what these differences in the morphology of the vasa mean for the reproductive biology of these species, but the taller, columnar cells that make up the thicker portions of the vasa seem to indicate glandular activity, whose excretions could provide some benefit for the spermatozoa.

The spermathecae of E. albidus s. str. show a high degree of morphological variation. The ampulla can vary from being rather compact and circular, to a large irregular sac subdivided into a number of diverticula (Fig. 7). Diverticula were also observed in some specimens of E. albellus sp. nov. (Fig. 11e), but not in E. moebii and E. cf. krumbachi. In the last species, however, the ental part of the spermathecal duct is modified into a small, rounded chamber, distinctly set off from the round proper ampulla. In all four aforementioned species, the ectal ducts of the spermathecae were covered in glands cells. In some of our specimens, these glands appeared to cover the entirety of the ducts length, whereas others had the most ental part of the duct (adjacent to the ampulla), free of glands. We do not know whether the degree of gland coverage is an important distinguishing feature between any of these species, and obviously when studying whole-mounted specimens, the interpretation of this coverage may vary depending on the angle from which these structures are viewed.

\section{Distribution and habitat}

As this investigation is based predominantly on European material of the E. albidus species complex (see Fig. 1, Table 1), we are unable to judge the genetic (and thus taxonomic) status of, e.g., Altman's (1936) North American E. multiannulatus and E. multiannulatoides. However, we have shown that at least $E$. albidus s. str. and E. albellus sp. $\mathrm{n}$. are geographically extending into the Arctic region (both occurring in Greenland, and northernmost Norway; E. albidus 
also in Svalbard at $>79^{\circ} \mathrm{N}$ ), while the northernmost record of E. moebii is from Narvik, at $68.5^{\circ} \mathrm{N}$ on the Norwegian coast. On the other hand, we found $E$. moebii, together with $E$. cf. krumbachi, in Galicia (Spain) at $42.6^{\circ} \mathrm{N}$, indicating that these two species are more southern than E. albidus and E. albellus.

Out of our 56 different localities (Table 1), 46 are influenced by saltwater (seashores above the high-water line, or the intertidal zone below this line), six sites are terrestrial (composts, lab cultures, and in one case, wet soil), and four are in freshwater (lake littoral, in one case a spring). Nine of the 10 non-marine sites (i.e., excluding the one of E. polatdemiri) were inhabited by E. albidus s. str. only. The marine littoral localities, on the other hand, were home to all except one of the species of the group studied; the exception is E. polatdemiri, specialized to live in a strongly alkaline soda lake (Arslan et al. 2018). In North European seashores, more than one species may occur in the same sample: we found E. albidus s. str. together with E. moebii in five, E. albidus s. str. with E. albellus in one, and E. moebii and E. albellus also in one of our samples (details in Table 1). In a beach at Rombaken Fjord (Narvik, Norway), all three species were found within meters from each other.

Thus, only E. albidus s. str. is to be expected outside seashore habitats, while all the other species studied (except E. polatdemiri) can be expected to occur in organic debris in the littoral or supralittoral zones of European beaches. As mentioned in the "Remarks" for E. albidus s. str. above, this is in accord with our designation of a neotype from a lab culture of E. albidus. Henle (1837) reported his species from moist soil and flowerpots. He also noted that, although normally living in moist substrates, the worms survived for 2 weeks in fresh water, suggesting an origin in a semiaquatic lifestyle. We found E. albidus s. str. under natural lake and spring conditions in mainland Norway and Svalbard (Table 1), and we noted above that wild strains of this species may survive in laboratory cultures regardless of their marine or inland habitat.

\section{Using E. albidus as a model organism}

The source populations of current laboratory cultures of white worms are probably in many cases unknown. This is a potential problem, as with a marine origin, the alleged E. albidus (s. str.) may have been either replaced by or mixed-in with other species of the complex treated in this study. For this reason, we here selected a specimen from a German lab culture, morphologically identified as Henle's E. albidus and COI barcoded, as the neotype of this species, allowing continued use of this name in, e.g., ecotoxicology studies. Laboratory use of specimens collected directly from seashores in the wild are not recommended without proper species identification, preferably by barcoding, as the other Enchytraeus species, although being very closely related, may have different biological and ecophysiological characteristics. The continued use of genetically established laboratory cultures is thus recommended for accuracy and repeatability in research using this taxon as a model or standard test organism.

\section{Conclusion}

For the seashores of Northern Europe and the Arctic, this study has recognized two taxa, E. moebii and E. albellus sp. nov., each defined as genetically as well as morphologically different from E. albidus s. str. However, the Mediterranean and NW Atlantic taxa in the E. albidus complex are still poorly sampled, and resolving the taxonomy of these more southern forms will have to be postponed to future research. For instance, the collection of fully mature specimens of the so-far-unidentified Mediterranean lineage E. sp.1, and its possession, or not, of spermathecal ectal glands will help to understand whether it shares more features with either Čejka's E. krumbachi or with Michaelsen's E. mediterraneus.

Acknowledgements We are grateful to A. Ansebo, M. Johansson, J.-H. Lee, L. Matamoros, and T. Struck, for assistance in the field, work; to M. Amorim, N. Arslan, E. Boräng, T. Ekrem, A. Haller, B. Reboreda Boreda, J. Römbke, and P. Samsson, for providing samples; and to A. Ansebo, B. Cronholm, M. Ericsson, P. Hjelmstedt, S. Kvist, E. Lindquist, M. Lindström, U. Olsson, and M. Svensson, for skillful assistance in the molecular lab. We also thank J. Römbke for important information about his lab cultures of Enchytraeus albidus, and R. Schmelz for habitat data on his Irish and Spanish material. The study was funded by the Swedish Research Council for Environment, Agricultural Sciences and Spatial Planning (FORMAS), Swedish Research Council (VR), Swedish Species Information Centre (ArtDatabanken), the Norwegian Biodiversity Information Centre (Artsdatabanken), the Adlerbert Research Foundation, and the Royal Society of Arts and Sciences in Gothenburg (KVVS); and for SM by ForBio (Research School in Biosystematics supported by the Norwegian Taxonomy Initiative and the Research Council of Norway), for his field work in Greenland, and by KVVS.

\section{Compliance with ethical standards}

Conflict of interest The authors declare that they have no competing interests.

Open Access This article is distributed under the terms of the Creative Commons Attribution 4.0 International License (http:// creativecommons.org/licenses/by/4.0/), which permits unrestricted use, distribution, and reproduction in any medium, provided you give appropriate credit to the original author(s) and the source, provide a link to the Creative Commons license, and indicate if changes were made.

\section{References}

Altman, L. C. (1936). Oligochaeta of Washington. University of Washington Publications in Biology, 4(1), 1-137. 
Amorim, M. J. B., Novais, S. C., Römbke, J., \& Soares, A. M. V. M. (2008). Enchytraeus albidus (Enchytraeidae): a test organism in a standardized avoidance test? Effects of different chemical substances. Environment International, 34, 363-371. https://doi.org/ 10.1016/j.envint.2007.08.010.

Amorim, M. J. B., Novais, S. C., Van Der Ven, K., Vandenbrouck, T., Soares, A. M. V. M., \& De Coen, W. (2011). Development of microarray for Enchytraeus albidus (Oligochaeta): preliminary tool with diverse applications. Environmental Toxicology and Chemistry, 30, 1395-1402. https://doi.org/10.1002/etc.512.

Arslan, N., Timm, T., Rojo, V., Vizcaíno, A., \& Schmelz, R. M. (2018). A new species of Enchytraeus (Enchytraeidae, Oligochaeta) from the profundal of Lake Van, the world's largest soda lake (Turkey, East Anatolia). Zootaxa, 4382(2), 367-380. https://doi.org/10.11646/ zootaxa.4382.2.8.

Backlund, H. O. (1947). Swedish Enchytraeida II. Kungliga Fysiografiska Sällskapets Handlingar, N.F. 58, 3-31.

Bell, A. W. (1958). The anatomy of the oligochaete Enchytraeus albidus, with a key to the species of the genus Enchytraeus. American Museum Novitates, New York, 1902, 1-13.

de Boer, T. E., Roelofs, D., Vooijs, R., Holmstrup, M., \& Amorim, M. J. (2018). Population-specific transcriptional differences associated with freeze tolerance in a terrestrial worm. Ecology and Evolution, 8(7), 3774-3786. https://doi.org/10.1002/ece3.3602.

Čejka, B. (1913). Litorea krumbachi n. spec. n. gen. - Ein Beitrag zur Systematik der Enchytraeiden. Zoologischer Anzeiger, 17, 145-151.

Christensen, B., \& Glenner, H. (2010). Molecular phylogeny of Enchytraeidae (Oligochaeta) indicates separate invasions of the terrestrial environment. Journal of Zoological Systematics and Evolutionary Research, 48(3), 208-212. https://doi.org/10.1111/j. 1439-0469.2009.00558.x.

Claparède, E. (1861). Recherches anatomiques sur les Annelides, Turbellariés, Opalines et Gregarines observées dans les Hébrides. Mémoires de la Société de Physique et d'Histoire Naturelle de Genève, 16(1), 71-164.

Drummond, A. J., \& Rambaut, A. (2007). BEAST: Bayesian evolutionary analysis by sampling trees. BMC Evolutionary Biology, 7, 214. https://doi.org/10.1186/1471-2148-7-214.

Drummond, A. J., Suchard, M. A., Xie, D., \& Rambaut, A. (2012). Bayesian phylogenetics with BEAUti and the BEAST 1.7. Molecular Biology and Evolution, 29, 1969-1973. https://doi.org/ 10.1093/molbev/mss075.

Erséus, C., \& Gustafsson, D. (2009). Cryptic speciation in clitellate model organisms. In Annelids in modern biology (pp. 31-46). Hoboken: John Wiley \& Sons.

Erséus, C., Rota, E., Matamoros, L., \& De Wit, P. (2010). Molecular phylogeny of Enchytraeidae (Annelida, Clitellata). Molecular Phylogenetics and Evolution, 57, 849-858. https://doi.org/10. 1016/j.ympev.2010.07.005.

Friend, H. (1899). New British annelids. The Zoologist Series, 4(3), 262 265.

Gomes, S. I. L., Soares, A. M. V. M., Scott-Fordsmand, J. J., \& Amorim, M. J. B. (2013). Mechanisms of response to silver nanoparticles on Enchytraeus albidus (Oligochaeta): survival, reproduction and gene expression. Journal of Hazardous Materials, 254(255), 336-344. https://doi.org/10.1016/j.jhazmat.2013.04.005.

Goodrich, E. S. (1897). Notes on oligochaetes, with the description of a new species. The Quarterly Journal of Microscopical Science, 39, 51-69.

Hebert P. D. N., Cywinska, A., Ball, S. L., \& DeWaard J. R. (2003). Biological identifications through DNA barcodes. Proceedings of the Royal Society of London B, Biological Sciences, 270, 313321. https://doi.org/10.1098/rspb.2002.2218 .

Henle, F. G. J. (1837). Ueber Enchytraeus, eine neue Anneliden-Gattung. Müllers Archiv für Anatomie, Physiologie und Wissenschaftliche Medizin, Berlin, 1837, 74-90.

Hrabě, S. (1935). Oligohety ozera Issyk-Kul. Die Oligochaeten des Issykkulsees. (The oligochaetes of Lake Issyk-Kul. In Russian with German summary.) Akademiya Nauk SSSR, Trudy Kirgizskoj kompleksnoj expedicii, 3, 73-85.

Kasprzak, K. (1986). Skaposzczety wodne i glebowe, II. Rodzina: Wazonkowce (Enchytraeidae). Warszawa: Polska Akademia Nauk Instytyt Zoologii, 366 pp.

Lasserre, P., \& Erséus, C. (1976). Oligochètes marins des Bermudes. Nouvelle espèces et remarques sur la distribution géographique de quelques Tubificidae and Enchytraeidae. Cahiers de Biologie Marine, 17, 447-462.

Librado, P., \& Rozas, J. (2009). DnaSP v5: a software for comprehensive analysis of DNA polymorphism data. Bioinformatics, 25, 14511452. https://doi.org/10.1093/bioinformatics/btp187.

Lock, K., Janssen, C. R., \& de Coen, W. M. (2000). Multivariate test designs to assess the influence of zinc and cadmium bioavailability in soils on the toxicity to Enchytraeus albidus. Environmental Toxicology and Chemistry, 19, 2666-2671. https://doi.org/10. 1002/etc.5620191108.

Martin, P., Martinsson, S., Wuillot, J., \& Erséus, C. (2018). Integrative species delimitation and phylogeny of the branchiate worm Branchiodrilus (Clitellata, Naididae). Zoologica Scripta, 47, 727742. https://doi.org/10.1111/zsc. 12316.

Martinsson, S., \& Erséus, C. (2017). Cryptic speciation and limited hybridization within Lumbricus earthworms (Clitellata: Lumbricidae). Molecular Phylogenetics and Evolution, 106, 18-27. https://doi.org/ 10.1016/j.ympev.2016.09.011.

Martinsson, S., \& Erséus, C. (2018a). Cryptic diversity in supposedly species-poor genera of Enchytraeidae (Annelida: Clitellata). Zoological Journal of the Linnean Society, 183, 749-762. https:// doi.org/10.1093/zoolinnean/zlx084.

Martinsson, S., \& Erséus, C. (2018b). Hybridisation and species delimitation of Scandinavian Eisenia spp. (Clitellata: Lumbricidae). European Journal of Soil Biology, 88, 41-47. https://doi.org/10. 1016/j.ejsobi.2018.06.003.

Michaelsen, W. (1885). Vorläufige Mittheilungen über Archenchytraeus Möbii n. sp. Zoologischer Anzeiger, 8, 237-239.

Michaelsen, W. (1886). Untersuchungen über Enchytraeus Möbii Mich. und andere Enchytraeiden. Kiel: Lipsius \& Tischer, $52 \mathrm{pp}$.

Michaelsen, W. (1900). Das Tierreich. Vol. 10, Oligochaeta. Berlin: Friedländer \& Sohn, 575 pp.

Michaelsen, W. (1926). Zur Kenntnis einheimischer und ausländischer Oligochäten. Zoologische Jahrbücher Abteilung für Systematik, Geographie und Biologie der Tiere, 51, 255-328.

Nielsen, C. O., \& Christensen, B. (1959). The Enchytraeidae. Critical revision and taxonomy of European species (Studies on Enchytraeidae VII). Natura Jutlandica, 8-9, 1-160.

Rannala, B., \& Yang, Z. (2013). Improved reversible jump algorithms for Bayesian species delimitation. Genetics, 194, 245-253. https://doi. org/10.1534/genetics.112.149039.

Reynolds, J. W., \& Wetzel, M. J. (2017). Nomenclatura Oligochaetologica - a catalogue of names, descriptions and type specimens. Editio Secunda. URL: http://wwx.inhs.illinois.edu/ people/mjwetzel/nomenoligo (accessed: September 2018).

Robinson, V. (1921). The life of Jacob Henle. New York: Medical Life Company, $117 \mathrm{pp}$.

Römbke, J. (1989). Enchytraeus albidus (Enchytraeidae, Oligochaeta) as a test organism in terrestrial laboratory systems. In: Chambers P. L., 
Chambers C. M., Greim H. (eds), Biological monitoring of exposure and the response at the subcellular level to toxic substances. Archives of toxicology, supplement 13, 402-405. Berlin, Heidelberg: Springer.

Römbke, J., \& Moser, T. (2002). Validating the enchytraeid reproduction test: organisation and results of an international ringtest. Chemosphere, 46, 1117-1140.

Ronquist, F., Teslenko, M., van der Mark, P., Ayres, D. L., Darling, A., Höhna, S., Larget, B., Liu, L., Suchard, M. A., \& Huelsenbeck, J. P. (2012). MrBayes 3.2: Efficient bayesian phylogenetic inference and model choice across a large model space. Systematic Biology, 61, 539-542. https://doi.org/10.1093/sysbio/sys029.

Schmelz, R. M., \& Collado, R. (2010). A guide to European terrestrial and freshwater species of Enchytraeidae (Oligochaeta). Soil Organisms, 82, 1-176.

Smith, F. (1895). Notes on species of North American Oligochaeta. Bulletin of the Illinois State Laboratory of Natural History, 4(8), 285-297.

Southern, R. (1906). Notes on the genus Enchytraeus, with description of a new species. The Irish Naturalist, 15(8), 179-185.

Stephens, M., \& Donnelly, P. (2003). A comparison of Bayesian methods for haplotype reconstruction from population genotype data. American Journal of Human Genetics, 73, 1162-1169. https://doi. org/10.1086/379378.

Stephens, M., Smith, N. J., \& Donnelly, P. (2001). A new statistical method for haplotype reconstruction from population data. American Journal of Human Genetics, 68, 978-989. https://doi. org/10.1086/319501.

Stirrup, H. H. (1913). A descriptive study of an oligochaete worm of the family Enchytraeidae, with an appendix on certain commensal protozoa. Proceedings of the Zoological Society of London, 87, 300-321.
Taheri, S., James, S., Roy, V., Decaëns, T., Williams, B. W., Andersson, F., Dupont, L., et al. (2018). Complex taxonomy of the 'brush tail' peregrine earthworm Pontoscolex corethrurus. Molecular Phylogenetics and Evolution, 124, 60-70. https://doi.org/10.1016/ j.ympev.2018.02.021.

Tamura, K., Stecher, G., Peterson, D., Filipski, A., \& Kumar, S. (2013). MEGA6: molecular evolutionary genetics analysis version 6.0. Molecular Biology and Evolution, 30, 2725-2729. https://doi.org/ 10.1093/molbev/mst197.

Vejdovský, F. (1879). Beiträge zur vergleichenden Morphologie der Anneliden. I. Monographie der Enchytraeiden. Prag: Verlag von Friedrich Tempsky, 61 pp.

Verrill, A. E., \& Smith, S. I. (1874). Report upon the invertebrate animals of Vineyard Sound and adjacent waters, with an account of the physical features of the region. Washington, DC: US Government Printing Office, $478 \mathrm{pp}$. [Extract of Report of Professor S.F. Baird, Commissioner of Fish and Fisheries, on the conditions of the sea fisheries of the south coast of New England in 1871 and 1872, pp. 295-852].

Yang, Z., \& Rannala, B. (2010). Bayesian species delimitation using multilocus sequence data. Proceedings of the National Academy of Sciences of the United States of America, 107, 9264-9269. https:// doi.org/10.1073/pnas.0913022107.

Yang, Z., \& Rannala, B. (2014). Unguided species delimitation using DNA sequence data from multiple loci. Molecular Biology and Evolution, 31, 3125-3135. https://doi.org/10.1093/molbev/msu279.

Publisher's note Springer Nature remains neutral with regard to jurisdictional claims in published maps and institutional affiliations. 